\title{
Evaluation of Proximate, Sugars and Mineral Compositions of 48 Yam (Dioscorea rotundata) Cultivars used as Parents in a Breeding Program in Republic of Benin
}

\author{
Fakorede Jeannette ${ }^{1}$, Sanoussi Faouziath ${ }^{1}$, Loko Yêyinou Laura Estelle ${ }^{2}$, \\ Dassou G. Anicet ${ }^{1}$, Tchekessi Célestin ${ }^{3}$, Ogundipe Oladeinde ${ }^{4}$, \\ Bokossa Yahou Innocent ${ }^{3}$ and Dansi A. Alexandre ${ }^{1^{*}}$ \\ ${ }^{1}$ Laboratory of Biotechnology, Genetic Resources and Plant and Animal \\ Breeding (BIORAVE), Faculty of Science and Techniques of Dassa, \\ PO Box 143 Dassa-Zoume, Benin \\ ${ }^{2}$ National High School of Applied Biosciences and Biotechnologies (ENSBBA), \\ National University of Sciences, Technologies, Engineering and Mathematics, \\ BP 14 Dassa, Benin \\ ${ }^{3}$ Food Safety Research Unit, University of Abomey-Calavi (UAC), \\ Benin, 04BP 1107, Cotonou \\ ${ }^{4}$ Department of Food Technology, Yaba College of Technology, Yaba, Lagos, Nigeria
}

*Corresponding author

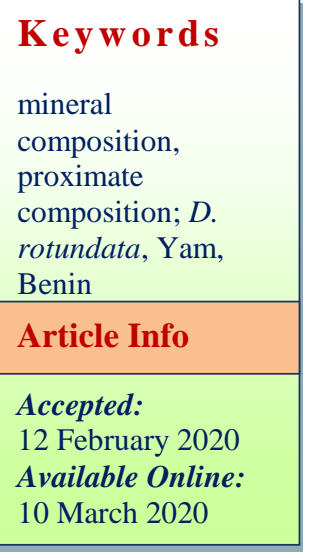

\section{A B S T R A C T}

Forty-eight cultivars (44 landraces and 4 hybrids) of white yam (Dioscorea rotundata Poir.) selected as parents for a breeding program in Benin were evaluated for proximate, sugars and mineral composition using standard AOAC methods. The results revealed a great variation among cultivars for fat $(2.4-18 \mathrm{mg} / \mathrm{g})$, protein $(0.40-19.31 \mathrm{mg} / \mathrm{g})$, total sugars $(28.60-498.97$ $\mathrm{mg} / \mathrm{g})$, reducing sugars $(50-156.27 \mathrm{mg} / \mathrm{g})$, and starch $(44.82-400.41 \mathrm{mg} / \mathrm{g})$ content. Variations in mineral content $(\mathrm{mg} / 100 \mathrm{~g})$ were also noted among cultivars for Calcium (12.20 to $560.80 \mathrm{mg}$ ), Magnesium, (1.65 to 1630.80 $\mathrm{mg}$ ), Iron, (1.79 to $22.60 \mathrm{mg})$, Zinc (0.55 to $20.03 \mathrm{mg}$ ) and Phosphorus (13.08 to $152.48 \mathrm{mg}$ ). Fat content were positively correlated with starch and negatively correlated with protein content. UPGMA cluster analysis assembled cultivars into 03 groups (G1, G2, G3). Cultivars of G1 and G3 are characterized with higher levels of sugars, lipids, proteins, starch, dry matter and significant mineral content. They appear to be more promising for involvement in breeding programs. 


\section{Introduction}

Yams are tuber plants grown as annual species in tropical regions of all continents (Gomez et al., 2019). Production in West and Central Africa accounts for about $96.4 \%$ of global production (FAO 2018). In West Africa, a dozen species of yam are produced but the species Dioscorea rotundata Poir known as white yam is the most important from the standpoint of calories, also the most cultivated and the most consumed (Delali et al., 2016). It is an important source of carbohydrate and other nutrients such as fibre, proteins, minerals, sugars, lipids and vitamins (Nwankwo, 2019).

With 2944944 tons of fresh tubers produce in 2018, Republic of Benin ranks fourth in production of yams after Nigeria, Côted'Ivoire and Ghana (FAO 2018). In Benin, yam remains the dietary food staple of Central and Northern populations (Egah and Baco, 2011) and has an image of prestigious products with high nutritional and dietetic values that allows it to withstand competition from other starches such as cereals and cassava. D. rotundata yams provide nearly $70 \%$ of the Beninese population's diet (Loko et al., 2013) and contribute significantly to meeting food needs (Baco et al., 2007, Yalou et al., 2015).

Consumption of yam is high in its production areas where it can provide more than one third of caloric inputs (Adejumo et al., 2013; Yalou et al., 2015). Modes of cooking of yam for consumption include but is not limited to boiling, pounding, flaking, roasting, frying, drying and processing into yam flour.

It can also be used as a raw material for the production of various products such as cookies, infant flour, syrups, etc. (Akinoso and Olatoye 2013). It is a major source of income for producers, and contributes significantly to reducing poverty and improving living condition for people (Loko et al., 2013).

Despite the good agronomic and nutritional characteristics of yam mentioned above, its production is still subject to many constraints, among with the susceptibility to biotic (pests, diseases, weeds) and abiotic (poor soils, drought; high soil moisture) factors. To develop improved varieties with novel characteristics that meet farmer's needs, a national breeding program has been established.

High yield, resistance or tolerance to diseases (anthracnose and YMV) and nematodes, tolerance to drought, good storability, good food quality (taste, poundability, elasticity, etc.) and high nutritional value are the attributes targeted for the improved varieties to be developed.

Based on existing yam database, 48 cultivars were selected as parents for different crosses to generate hybrids of different natures derived from opened pollination or manual crossing. To generate varieties with high nutritional value, selection of parents of interesting and complementary nutritional profiles (proximate and mineral composition) is a prerequisite.

The objectives of this study are three-folds: Assess the proximate, sugars and mineral compositions of the 48 cultivars of the Benin yam breeding collection.

Analyse the relationship between the different nutritional value parameters investigated.

Identify the best genotypes within the collection that can be directly valorised in the yam value chain or involved in a crossing scheme to generate novel varieties. 


\section{Materials and Methods}

\section{Sampling and samples preparation}

Tubers of forty-eight (48) yam (D. rotundata) cultivars consisting of 44 landraces and 4 hybrids derived from OP (opened pollination) with the female cultivar Ahimon were sampled for evaluation (Table 1). The landraces were identified from different production areas among those having a good market value and cultivated by many houses and on large areas.

After washing with tap water and cleaning with paper towels, the tubers of the different cultivars were peeled separately and cut into small pieces using stainless steel kitchen knife. Pieces of each cultivar were then pounded with a mortar. A quantity of $250 \mathrm{~g}$ of the pulp obtained from the samples of each cultivar was homogenized and then stored aseptically in a polyethylene bag at $18{ }^{\circ} \mathrm{C}$ for their physicochemical characterization.

\section{Proximate composition analysis}

Homogenized samples of tuber of each cultivar was analyzed for dry mater, protein, fat, and ash. Each chemical analysis was carried out in triplicates following the standard method described by Association of Official Analytical Chemists (AOAC 1990; AOAC 2000).

Dry matter content was determined using the AOAC (1990) method. $5 \mathrm{~g}$ of sample, was dried in an oven at atmospheric pressure, and at the temperature of $103 \pm 2{ }^{\circ} \mathrm{C}$ for 24 hours until a constant weight was obtained.

Protein content was determined using Kjeldahl's method described by AOAC (1990). This method consists first of mineralizing the proteins, then distilling and measuring the formed ammonia. Percentage of crude protein was calculated by multiplying nitrogen percentage to protein factor 6.25 .

Total fat in samples was determined using the hot soxhlet extraction method by Bourely (1982).

Ash content was obtained after combustion was done in muffle furnace at $550{ }^{\circ} \mathrm{C}$ until white ash was obtained (after 48 hours) following Wolff (1972). Percentage ash was expressed relative to $100 \mathrm{~g}$ of dry product by the ratio: Ashes $(\%)=\left[\left(\mathrm{M}_{1}-\mathrm{M}_{0}\right) / \mathrm{M}\right] \times 100$ (Soro, 2013). where $M_{1}=$ final weight (hollow + calcined sample), $\mathrm{M}=$ sample weight in $\mathrm{g}, \mathrm{M}_{0}=$ crucible empty weight in $\mathrm{g}$.

Total carbohydrates was determined using the method of Bertrand and Thomas (1910). The calculation was made with the determined values of protein, lipid, ash and moisture levels. Carbohydrate was determined using the difference method \%Total carbohydrates $=100-[\% \mathrm{~A}+\% \mathrm{P}+\% \mathrm{~L}+\% \mathrm{M}]$ where $\mathrm{A}=$ ash, $\mathrm{P}=$ Protein, $\mathrm{L}=$ Lipid and $\mathrm{M}=$ Moisture content

Energy value of each sample was calculated by multiplying the protein rate by $4(\mathrm{Kcal} / \mathrm{g})$, the lipid rate by $9(\mathrm{Kcal} / \mathrm{g})$ and the total carbohydrate value by $4 \mathrm{Kcal} / \mathrm{g}$. The energy value in Kcal was calculated using the Atwater and Benedict (1902) equation. Energy $(\mathrm{Kcal})=[(9 \mathrm{x}$ Fat $(\%)+4 \mathrm{x}$ Protein $(\%)+4 \times$ carbohydrates $(\%)]$.

\section{Sugar content analysis}

Determination of total sugars and reducing sugars was carried out using the spectrophotometric method. For total sugars, sample solutions were prepared using phenol and sulphuric acid as a reagent and absorbance was read by the spectrophotometer (Biomate 3) at 490 
nanometer (Njintang et al., 2007). Reducing sugars were determined using the same processes as total sugars, with Di-NitroSulfate (DNS) used as a reagent, and absorbance read at 546 nanometer.

Starch and amylose content were determined using also the spectrophotometric method. A mass of $0.5 \mathrm{~g}$ sample was neutralized by addition of potassium hydroxide $(\mathrm{KOH}) 1 \mathrm{M}$ and a concentrated hydrochloric acid (HCL) solution, $1 \mathrm{M}$ until $\mathrm{pH}=7$. The supernatant of the concentrated solutions thus prepared and their dilutions were transferred into reading tanks of the spectrophotometer and the absorbance was read at 580 nanometers for starch and at 720 nanometers for amylose.

\section{Mineral composition analysis}

Mineral composition was determined in each diluted ash using spectrophotometry and titrimetry methods following Wada et al., (2019). Zinc ( $\mathrm{Zn})$, iron (Fe), phosphorus (P) and iodine (I) were determined by molecular Absorption using DR 2800 spectrophotometer, while $\mathrm{Ca}^{2+}$ and $\mathrm{Mg}^{2+}$ were determined by titrimetry using the Digital burette and EDTA method (Tegegne et al., 2020). The iodine is measured using the $\mathrm{DPD}_{4}$ reagent. The following wavelengths were used: $510 \mathrm{~nm}$ for iron, 620nm for zinc, and $880 \mathrm{~nm}$ for phosphorus. The analyses were performed according to AOAC (2009). The results were obtained after three readings of each triplicate and expressed in $\mathrm{g} / 100 \mathrm{~g}$.

\section{Statistical analysis of data}

Three values were taken for each parameter and cultivar. Data collected were analyzed using descriptive statistics (mean, percentage, standard deviation, etc.) and Pearson's coefficient of correlation with Mini tab software (Minitab 2017). Analysis of variance (ANOVA) and Newman-Keul test (with a
95\% confidence level) were performed with $\mathrm{R}$ software to compare the differences between the mean values of proximate, sugar and mineral compositions. Pearson coefficient of correlation were generated to examine the correlation between variables. A dendrogram was also generated to classify cultivars according to their nutritional characteristics using the UPGMA cluster analysis.

\section{Results and Discussion}

\section{Proximate and sugars composition}

Analysis of the results of the various parameters studied (Table 2) showed that the dry matter content (DM) varies from $28.24 \%$ to $43.07 \%$ while ash content varies from 0.37 $\mathrm{mg} / \mathrm{g}$ to $1.11 \mathrm{mg} / \mathrm{g}$ in the various cultivars of D. rotundata analyzed. Hybrid Dr-A39-2003 $(42.90 \%)$ and the cultivar Portchahabim $(43.07 \%)$ recorded the highest dry matter content while the cultivars Adani $(1.11 \mathrm{mg} / \mathrm{g})$, Wokourou $(0.88 \mathrm{mg} / \mathrm{g})$ and Môrôkorou $(0.82$ $\mathrm{mg} / \mathrm{g}$ ) have the highest ash content levels respectively. Significant $(\mathrm{P}<0.05)$ difference was observed among the samples for their dry matter content while for the ash content there was no significant $(\mathrm{P}<0.05)$ difference observed.

Low lipid content was revealed in the yam samples evaluated with significant difference $(\mathrm{P}<0.05)$ between cultivars. Values obtained ranged from $2.4 \mathrm{mg} / \mathrm{g}$ to $18 \mathrm{mg} / \mathrm{g}$ with an average of $8.29 \mathrm{mg} / \mathrm{g}$. Highest lipid levels were observed in cultivars Kpagninan and Labôkô while cultivar Gaboubaba showed the lowest lipid level (Table 2). Early maturing (double harvest) cultivars tends to have a relatively higher lipid levels when compared to late maturing (single harvest) ones.

Sugar was the energy component found in large quantity in the 48 cultivars assessed. Sugars content varies from 28.60 to 498.97 
$\mathrm{mg} / \mathrm{g}$ for total sugars and from 12.50 to $156.27 \mathrm{mg} / \mathrm{g}$ for reducing sugars with an average of $269.3 \mathrm{mg} / \mathrm{g}$ and $47.74 \mathrm{mg} / \mathrm{g}$ respectively. A significant difference $(\mathrm{P}<$ 0.05) was observed for both total and reducing sugar content of the samples analyzed. Cultivars Wokourou and DrA392003 differ from the others due to their high levels of total sugars and Kpagninan due to its high reducing sugars content. Over $95 \%$ of the cultivars analysed contain relatively low rates of reducing sugar compared to total sugars. Cultivars Assina and Bobotchinga have very low sugar levels.

Protein content ranged between $0.47 \mathrm{mg} / \mathrm{g}$ and $19.31 \mathrm{mg} / \mathrm{g}$, with an average of 8.87 mg/g. Cultivars Amoula, Kagourou, Tchee and Singor have the highest levels of protein, while cultivar Anklouman recorded the lowest level of protein. Significant difference $(\mathrm{P}<$ 0.05) was observed between cultivars except Amoula, Tchee, Kagourou and Singor which showed similar protein content (no significant difference).

The carbohydrate content varied between $9.80 \%$ and $40.35 \%$, with an average value of $31.07 \%$. Hybrid Dr-A39-2003 (40.35\%), cultivars Portchahabim (39.82\%), Gominin $(39.10 \%)$ recorded the highest values for carbohydrate. All cultivars studied contain high carbohydrate levels. Significant $(\mathrm{P}<$ 0.05) difference was observed between the samples studied in terms of carbohydrates content.

Starch, amylose and amylopectin content in these cultivars varied between $44.82 \mathrm{mg} / \mathrm{g}$ and $400.41 \mathrm{mg} / \mathrm{g}, 50.18 \mathrm{mg} / \mathrm{g}$ and $326.83 \mathrm{mg} / \mathrm{g}$ and $3.74 \mathrm{mg} / \mathrm{g}$ and $201.18 \mathrm{mg} / \mathrm{g}$ respectively with the mean being $178.6 \mathrm{mg} / \mathrm{g}, 135.88 \mathrm{mg} / \mathrm{g}$ and $40.04 \mathrm{mg} / \mathrm{g}$ respectively. Cultivars Anklouman and Dr-A5-2003 have the highest levels of starch, amylose and amylopectin. All the cultivars studied contain high starch levels. For each cultivar, studied amylose content was observed to be proportional to starch content, except for the cultivar Labôkô $(91.60 \mathrm{mg} / \mathrm{g})$. All the cultivars examined were significantly $(\mathrm{P}<0.05)$ different, except Singor, Portchahabim and Adani which were statistically similar with respect to their starch content.

Energy value of the 48 cultivars varies between $44.64 \mathrm{kcal} / 100 \mathrm{~g}$ and 173.22 $\mathrm{kcal} / 100 \mathrm{~g}$ with an average of 135.29 kcal/100g. Cultivars Portchahabim, Kagourou and the hybrid DrA39-2003 recorded the highest energy values.

Descriptive statistics (Table 3) indicates high variability in all of the variables except for energy value, carbohydrate and dry matter content, which show the lower variability with coefficients of variation of $16.75,8.27$ and 14.57 respectively. The greatest variations were obtained for amylopectin content (3.04-263.37) and total sugars (28.6499) with the respective coefficients of variation of 113.21 and 63.14.

A significant and positive correlation was observed between lipid, starch, amylose, dry matter and carbohydrates on one hand and protein and ash on the other hand. The reducing sugars content was strongly and negatively correlated with dry matter, starches and carbohydrates. Lipid content was positively correlated with starch, amylose and amylopectin, while a negative correlation was observed with protein content. In addition, the protein content of the samples was strongly and positively correlated with ash content but negatively correlated with amylopectin content (Table 4).

In the principal component analysis (PCA) performed using cultivars as individuals and parameters assessed as variables, the two first axis explain respectively $79.45 \%$ and $13.4 \%$ 
(92.80\%) of the variability between cultivars and the 48 cultivars are classified into three groups (Figure 1). The characteristics of each group are presented in table 5. Same results were obtained in the dendrogram constructed using UPGMA cluster analysis (Figure 2).

\section{Mineral composition}

Minerals represent important components of the foods, because of their metabolic functions in the body. Mineral (Iron, Zinc, Calcium, Magnesium, Phosphorus, and iodine) composition and its variability of the cultivars evaluated are presented in Tables 6 and 7. All the yam cultivars studied have not negligible amount of the mineral salts evaluated. The Iron content in the analyzed samples varies from 1.794 to $22.6 \mathrm{mg} / 100 \mathrm{~g}$ with an average of $8.169 \mathrm{mg} / 100 \mathrm{~g}$. The highest Iron content was found in the cultivar Yassi, while the cultivar Bakarou had the lowest Iron content. Phosphorus content ranged between $13.08 \mathrm{mg} / 100 \mathrm{~g}$ and 152.48 $\mathrm{mg} / 100 \mathrm{~g}$, with an average content of 51.96 $\mathrm{mg} / 100 \mathrm{~g}$. Cultivar Bakarou had a higher phosphorus content while cultivar Bobotchinga had the lowest phosphorus content. The calcium content of the 48 yam cultivars studied ranged between 12.2 $\mathrm{mg} / 100 \mathrm{~g}$ and $560.8 \mathrm{mg} / 100 \mathrm{~g}$ of fresh weight with an average of $171.9 \mathrm{mg} / 100 \mathrm{~g}$. Cultivars Angbaobé and Yonouan had high calcium levels while the cultivar Bakarou had a very low calcium content. Magnesium represents the most abundant mineral salt in almost all yam samples evaluated. The magnesium content of the samples variedd between 1.65 $\mathrm{mg} / 100 \mathrm{~g}$ and $1630.8 \mathrm{mg} / 100 \mathrm{~g}$ on fresh weight with an average of $285.5 \mathrm{mg} / 100 \mathrm{~g}$. Cultivar Môrôkôrou had the highest magnesium, while cultivar Gaboubaba recorded the lowest magnesium content. Zinc content of the cultivars evaluated varied from $0.550 \mathrm{mg} / \mathrm{g}$ to $20 \mathrm{mg} / \mathrm{g}$ while iodine content recorded stayed between $0.225 \mathrm{mg} / \mathrm{g}$ and $5.680 \mathrm{mg} / \mathrm{g}$.
Cultivars Tarayè (rich in zinc) and Kratchi (rich in iodine) differ from others with their higher levels of Zinc and iodine respectively. Calcium, Magnesium, and Phosphorus were the most abundant minerals in all $D$. rotundata cultivars analyzed while Iron, Zinc and iodine occur in small amount, with the exception of a few varieties, which have expressed slightly high levels. Following the analysis of these results, cultivars Angbaobé, Wokourou, Môrôkôrou, and Yakanogo appear to be the richest in minerals not only for their high levels in Calcium, Magnesium but also for the non-negligible levels in Iron, Zinc and Iodine.

Table 6 also shows $\mathrm{Ca} / \mathrm{Mg}$ and $\mathrm{Ca} / \mathrm{P}$ ratios of the analyzed samples. $\mathrm{Ca} / \mathrm{Mg}$ ratio ranged between 39.67 and 0.20. Gaboubaba cultivar (39.67) was found to have the highest ratio $\mathrm{Ca} / \mathrm{Mg}$ while the lowest ratio were obtained with Yakanogo (0.23) and Anklouman (0.29). $\mathrm{Ca} / \mathrm{P}$ ratio varied between 27.26 and 0.19 . Labôkô cultivar has the highest (27.26) $\mathrm{Ca} / \mathrm{P}$ ratio while the lowest ratios have been recorded with cultivars Singor and Yassi (0.19).

A high level of variability (Table 7) was observed among the variables measured for mineral composition. For instance, significant variability is observed between levels of $\mathrm{Mg}^{2+}$ (1.65 mg/100g - $1630.8 \mathrm{mg} / 100 \mathrm{~g}$ ) and $\mathrm{Ca}^{2+}$ $(12.2 \mathrm{mg} / 100 \mathrm{~g}-560 \mathrm{mg} / 100 \mathrm{~g})$ with regard to their higher coefficient of variations $\mathrm{CVs}$ (Table 7). The respective mean values for $\mathrm{Mg}^{2+}, \mathrm{Ca}^{2+}, \mathrm{Zn}$, Iron and I are $8.169 \mathrm{mg} / 100 \mathrm{~g}$, $6.923 \mathrm{mg} / 100 \mathrm{~g}, \quad 2.116 \mathrm{mg} / 100 \mathrm{~g}, \quad 51.9$ $\mathrm{mg} / 100 \mathrm{~g}, 171.9 \mathrm{mg} / 100 \mathrm{~g}$ and $285.5 \mathrm{mg} / 100 \mathrm{~g}$ respectively.

The analysis of variances carried out based on mineral composition revealed three groups (Table 8) within the cultivars analyzed. Group 1 (G1) assemble cultivars with high levels of Calcium, Magnesium and $\mathrm{Ca} / \mathrm{P}$ ratio with the 
respective averages values of $368.39 \pm$ $112.42,656.94 \pm 398$ and $12.26 \pm 5.51$. Group 2 (G2) cluster together cultivars characterized by a higher $\mathrm{Ca} / \mathrm{Mg}$ ratio $6.83 \pm$ 10.8. Group 3 (G3) assembles cultivars characterized by high levels of Zinc and Phosphorus with averages of $8.26 \pm 3.39$ and $65.50 \pm 25.98$ respectively.

The evaluation of the proximate and sugars composition of the 48 yam's cultivars use as parents in breeding programme in Benin revealed great variability among cultivars.

The dry matter content recorded $(28.24 \%$ to $43.07 \%)$ are similar to those (32.55 to 36.54 ) reported in the literature (Coulibaly et al., 2019) on cultivated yam species. High dry matter content would be more suitable for prolonged storage of tubers and industrial processing (Rose-Monde et al., 2009; More et al., 2019). Results of ash content in this study (0.37 to $1.1 \mathrm{~g} / 100 \mathrm{~g})$ are lower than those reported by Graham-Acquaah et al., (2012) in Ghana and those reported Padhan et al., (2020) in India on wild yam.

Values obtained for lipids ( 0.9 to $6.5 \mathrm{mg} / \mathrm{g}$ ) are higher than those reported by Mulualem et al., (2018), in southwest Ethiopia on other yam species. Among the 48 cultivars studied, cultivar Kpagninan of group 2 that recorded the highest lipid content can offer an appreciable organoleptic quality in the food formulations. In addition, lipids in foods of plant origin provide essential fatty acids that the organism is unable to synthesize, and that facilitate in maintaining the balance of the human body (Badau et al., 2013).

The protein levels ( 4.18 to $5.2 \mathrm{~g} / 100 \mathrm{~g}$ ) of the cultivars studied are similar to the values recorded by Umara and Emenyonu (2019) on yam germplasm in Nigeria and higher than those obtained by Degbeu et al., (2019) in Ivory Coast. Cultivar Amoula is rich in proteins as it recorded high protein content when compared to other cultivars.

Values obtained for carbohydrate content are lower than those (77.53 to 87 ) reported by Polycarp et al., (2012), on 13 species of Dioscorea in Ghana. Yam is an important source of carbohydrates amongst tubers for millions of individuals (Soro et al., 2013; Nwankwo 2019). This characteristic defines cultivars containing the higher carbohydrate levels (Portchahabim, Gominin, Dr-A392003, Labôkô) as good energy sources, vital for optimal functioning of the body. An increase in carbohydrate levels in some of yam cultivars studied could be beneficial for the metabolism and assimilation of other components.

The difference in sugar levels from one cultivar to another would be likely due to the fragility of their starches or related to their production cycle and the period in which the harvest was done (Polycarp et al., 2012). Cultivar Kpagninan, has potentials for industrial applications in the manufacture of ethanol.

The measured starch levels $(44.82 \mathrm{mg} / \mathrm{g}$ to $400.41 \mathrm{mg} / \mathrm{g}$ ) are similar to the findings by Ehui et al., (2009) in other cultivars of $D$. cayenensis-rotundata (kpounan) and D. alata (Florido). These variations could be due to the specific peculiarities of each yam cultivar, or the sensitivity of their starches, to the influence of climate change that tubers face in their agro-ecological zones. According to Ehui et al., (2009), the starch-lipid complex gradually hydrolyze at high temperatures, allowing amylopectin and its complex to diffuse outside the starch grain. Cultivar with the lowest amylopectin and high lipid levels such as Labôkô (13mg/g, $91.60 \mathrm{mg} / \mathrm{g})$ could be used in food-processing applications to provide derivatives of good organoleptic quality or appropriate texture as reported by Bahrani (2013). 
Result of mineral composition revealed existence of $D$. rotundata yam cultivars with high mineral salt potential. Mineral are important component of diet because of their physiological and metabolic function in body. The levels of calcium and magnesium in cultivars studied are higher (36 to 37 and 95 to $103 \mathrm{mg} / 100 \mathrm{~g}$ ) than those obtained by Medoua (2005) and less (than 132.02 $\mathrm{mg} / 100 \mathrm{~g}$ and $45.90 \mathrm{mg} / 100 \mathrm{~g}$ ) obtained by Alinnor and Akalezi (2010) in another variety of yam (D. rotundata) in Nigeria. These values are similar to those (103.25 to 27.00 $\mathrm{mg} / 100 \mathrm{~g}$ and 355.49 to $73.04 \mathrm{mg} / 100 \mathrm{~g}$ ) reported by Polycarpe et al., (2012), for seven species of yams grown in Ghana. Calcium plays an important role in blood clotting, muscle contraction, neurological function, and enzyme metabolism processes (Udensi et $a l ., 2008)$ in humans. The study shows that the calcium levels obtained (12.2 to 560.8 $\mathrm{mg} / \mathrm{g}$ ) for the 48 cultivars are lower than those recommended by the WHO (800 $\mathrm{mg} / \mathrm{g})$, consequently it can be deducted that yam is not a good source of calcium.

Magnesium plays an essential role in the metabolism of calcium in bones, in the prevention of circulatory diseases (Andzouana and Monbouli, 2012; Adjatin et al., 2013). All of these latter functions of the mineral could also be more assured by group 1 cultivars than other cultivars. All samples analyzed were found to be significant sources of magnesium, because they contribute to more than $10 \%$ and $15 \%$ of the recommended daily magnesium requirements of children and adults respectively. Iron and phosphorus levels are similar to the findings of Megh et al., (2002). Values obtained were however found to be lower than that reported by Nwankwo (2019) on selected yam landraces (D. rotundata). The difference observed could be related to differences between genotype studied, soil types, and environmental and climatic conditions as observed by Sanoussi et al., (2013). Iron content of some cultivars such as wokiri (13.65 mg/100g) and yaassi $(22.6 \mathrm{mg} / 100 \mathrm{~g})$ are higher than the WHO recommended daily allowance for children (10 mg/day) and adults (15 mg/day).

The $\mathrm{Ca} / \mathrm{P}$ ratio, $\mathrm{Ca} / \mathrm{Mg}$, are increasingly used by several authors to assess the nutritional benefits of different species and/or predict health benefits of a food (Andzouana and Mahouli, 2012; Adjatin et al., 2013). The result of the analysis indicates that $\mathrm{Ca} / \mathrm{P}$ ratio were higher than those obtained by Alinnor and Akalezi (2010) on D. rotundata and Colocasia esculenta species in Nigeria (2.42; 2.44). If the $\mathrm{Ca} / \mathrm{P}$ is low (low calcium, high phosporus intake), than the recommended level, calcium may be lost in the urine. The $\mathrm{Ca} / \mathrm{P}$ ratio is used to control the increase of calcium in the small intestine. Several authors have reported that food is considered good if the value of the $\mathrm{Ca} / \mathrm{P}$ ratio is greater than 1 , and poor, if the $\mathrm{Ca} / \mathrm{P}$ ratio is less than 0.5 (Alinor and Oze, 2011; Adjatin et al., 2013). Cultivars from group 1 with very high $\mathrm{Ca} / \mathrm{P}$ ratios could be considered as a good source of calcium rich food among the cultivars studied, so their consumption can then participate in fight against $\mathrm{Ca}$ deficiency. The $\mathrm{Ca} / \mathrm{Mg}$ ratio obtained in most of $D$. rotundata cultivars studied were above the recommended value of 1.00. The hierarchical classification according to the nutritional characteristics, allowed to obtain groups of cultivars with very interesting criteria. Group 1 (G1) cultivars gathered yam's cultivars with high starch, ash, lipid, sugar, carbohydrates and dry matter and low protein content. Yam's cultivars such characteristics could be involved in production of yam derivatives requiring an elastic character such as elastic pastes (Fufu, Amala, and pounded yam). 
Table.1 List of the cultivars studied (SH: single harvest; DH: double harvest)

\begin{tabular}{|c|c|c|c|c|c|c|}
\hline $\mathbf{S} / \mathbf{N}$ & Cultivar name & Major production zone & Earliness & $\begin{array}{l}\text { Quality of } \\
\text { boiled yam }\end{array}$ & $\begin{array}{l}\text { Quality of } \\
\text { pounded yam }\end{array}$ & $\begin{array}{l}\text { Quality of } \\
\text { Amala }\end{array}$ \\
\hline 1 & Adani & Sinende & $\mathrm{DH}$ & Good & Good & Fair \\
\hline 2 & Ahimon & Pehunco & DH & Good & Good & Fair \\
\hline 3 & Alsoura & Ouake & SH & Fair & Fair & Excellent \\
\hline 4 & Amoula & Bassila & DH & Good & Good & Fair \\
\hline 5 & Angbaobe & Sinende & $\mathrm{DH}$ & Good & Good & Fair \\
\hline 6 & Anklouman & Ouake & DH & Good & Good & Fair \\
\hline 7 & Assina & Djougou & $\mathrm{SH}$ & Good & Good & Excellent \\
\hline 8 & Babetei & Djougou & SH & Good & Good & Fair \\
\hline 9 & Bakarou & Copargo & $\mathrm{SH}$ & Good & Good & Excellent \\
\hline 10 & Banioure & Nikki & SH & Good & Good & Fair \\
\hline 11 & Bobotchinga & Toukountouna & DH & Good & Good & Fair \\
\hline 12 & Boniakpa & Sinende & SH & Good & Good & Excellent \\
\hline 13 & Dambani & Tchaourou & SH & Good & Good & Fair \\
\hline 14 & Deba & Tchaourou & $\mathrm{SH}$ & Good & Good & Excellent \\
\hline 15 & Djilaadja & Save & DH & Good & Good & Fair \\
\hline 16 & Dodo & Glazoué & $\mathrm{DH}$ & Good & Good & Fair \\
\hline 17 & DrA21-2003 & Dassa & $\mathrm{DH}$ & Good & Good & Fair \\
\hline 18 & DrA39-2003 & Dassa & $\mathrm{DH}$ & Good & Good & Fair \\
\hline 19 & DrA5-2003 & Dassa & DH & Good & Good & Fair \\
\hline 20 & DrA65-2003 & Dassa & DH & Good & Good & Fair \\
\hline 21 & Effourou & Savè & DH & Good & Good & Fair \\
\hline 22 & Gaboubaba & Savè & $\mathrm{DH}$ & Good & Good & Fair \\
\hline 23 & Gnidou & Djidja & DH & Good & Good & Fair \\
\hline 24 & Gominan & Perere & SH & Good & Good & Excellent \\
\hline 25 & Heapala & Ouake & DH & Good & Good & Fair \\
\hline 26 & Idoro & Djougou & $\mathrm{DH}$ & Good & Good & Fair \\
\hline 27 & Kagourou & Tchaourou & SH & Good & Good & Fair \\
\hline 28 & Katala & Bantè & $\mathrm{DH}$ & Good & Good & Fair \\
\hline 29 & Kpagninan & Bassila & SH & Good & Good & Fair \\
\hline 30 & Kpakara & Sinendé & DH & Good & Good & Fair \\
\hline 31 & Kpouna & Nikki & $\mathrm{DH}$ & Good & Good & Fair \\
\hline 32 & Kratchi & Glazoué & DH & Good & Good & Fair \\
\hline 33 & Laboko & Glazoue & $\mathrm{DH}$ & Good & Good & Fair \\
\hline 34 & Morokorou & Glazoué & $\mathrm{DH}$ & Good & Good & Fair \\
\hline 35 & Parayobou & Toukountouna & SH & Good & Good & Fair \\
\hline 36 & Portchabim & Djougou & SH & Good & Good & Excellent \\
\hline 37 & Singor & Tchaourou & $\mathrm{SH}$ & Good & Good & Excellent \\
\hline 38 & Soussouka & Toukountouna & DH & Good & Good & Fair \\
\hline 39 & Taraye & Djougou & $\mathrm{DH}$ & Good & Good & Fair \\
\hline 40 & Tchee & Toukountouna & $\mathrm{DH}$ & Good & Good & Fair \\
\hline 41 & Wete & Ouesse & DH & Good & Good & Fair \\
\hline 42 & Wokiri & Nikki & $\mathrm{DH}$ & Good & Good & Fair \\
\hline 43 & Wokourou & Nikki & $\mathrm{DH}$ & Good & Good & Fair \\
\hline 44 & Wouroutani & Djougou & $\mathrm{DH}$ & Good & Good & Fair \\
\hline 45 & Yaassi & Toukountouna & DH & Good & Good & Fair \\
\hline 46 & Yakanougo & Tchaourou & SH & Good & Good & Excellent \\
\hline 47 & Yonouan & Djougou & $\mathrm{DH}$ & Good & Good & Fair \\
\hline 48 & Zambe & Djougou & $\mathrm{DH}$ & Good & Good & Fair \\
\hline
\end{tabular}


Table.2 Proximate and sugar composition of the different yam (Dioscorea rotundata) cultivars studied

\begin{tabular}{|c|c|c|c|c|c|c|c|c|c|c|c|}
\hline Cultivar & $\begin{array}{c}\text { Total sugar } \\
(\mathrm{mg} / \mathrm{g})\end{array}$ & $\begin{array}{c}\text { Reducing } \\
\text { sugar }(\mathrm{mg} / \mathrm{g})\end{array}$ & Fat (mg/g) & $\begin{array}{c}\text { Proteins } \\
\text { (mg/g) }\end{array}$ & Starch $(\mathrm{mg} / \mathrm{g})$ & $\begin{array}{c}\text { Amylose } \\
(\mathrm{mg} / \mathrm{g})\end{array}$ & $\begin{array}{c}\text { Amylopectin } \\
(\mathrm{mg} / \mathrm{g})\end{array}$ & $\operatorname{Ash}(\%)$ & $\begin{array}{c}\text { Dry-mater } \\
(\%)\end{array}$ & $\begin{array}{c}\text { Carbohydrat } \\
\text { e }(\%)\end{array}$ & $\begin{array}{l}\text { Energy } \\
\text { (Kcal) }\end{array}$ \\
\hline Adaani & $432.81 \pm 1.5^{a}$ & $17.77 \pm 2.26^{\mathrm{qrs}}$ & $8.95 \pm 0.05^{\text {bcdi }}$ & $6.84 \pm 0.47^{\mathrm{hi}}$ & $157.97 \pm 0.44^{q}$ & $128.18 \pm 0.78^{\circ}$ & $29.7 \pm 0.34^{\mathrm{mn}}$ & $1.11 \pm 0.35^{\mathrm{a}}$ & $30.70 \pm 0.70^{\text {hij }}$ & $28.01 \pm 0.41^{\mathrm{a}}$ & $122.83 \pm 2^{p}$ \\
\hline Ahimon & $247.42 \pm 0.41^{\mathrm{r}}$ & $12.50 \pm 1.51^{\mathrm{s}}$ & $4.75 \pm 0.15^{\mathrm{ijk}}$ & $12.62 \pm 0.16^{\mathrm{bcd}}$ & $86.92 \pm 0.88^{\mathrm{B}}$ & $50.18 \pm 1.82^{x}$ & $36.74 \pm 0.94^{\mathrm{kl}}$ & $0.74 \pm 0.25^{\mathrm{a}}$ & $33.49 \pm 0.71^{\mathrm{hij}}$ & $31.01 \pm 0.3^{\mathrm{ab}}$ & $133.37 \pm 1^{\mathrm{e}}$ \\
\hline Alssoura & $479.82 \pm 0.53^{c}$ & $29.06 \pm 6.02^{\mathrm{Imp}}$ & $8.9 \pm 0.1^{\text {bcdi }}$ & $7.00 \pm 0.24^{\mathrm{hi}}$ & $114.33 \pm 1.10^{\mathrm{A}}$ & $101.14 \pm 0.26^{\mathrm{t}}$ & $13.19 \pm 0.8^{\mathrm{rs}}$ & $0.86 \pm 012^{\mathrm{a}}$ & $40.77 \pm 0.70^{\mathrm{ab}}$ & $38.32 \pm 0.48^{\mathrm{ab}}$ & $164.09 \pm 2^{1}$ \\
\hline Amoula & $413.50 \pm 1.91^{j}$ & $24.54 \pm 3.01^{\mathrm{opq}}$ & $11.2 \pm 0.1^{\text {bcde }}$ & $19.31 \pm 3.60^{\mathrm{a}}$ & $141.96 \pm 0.66^{\mathrm{st}}$ & $115.18 \pm 3.38^{\mathrm{rs}}$ & $26.78 \pm 2.72^{\mathrm{n}}$ & $0.65 \pm 0.31^{\mathrm{a}}$ & $34.20 \pm 0.70^{\text {ef }}$ & $30.49 \pm 0.25^{\mathrm{bc}}$ & $139.80 \pm 1^{\mathrm{k}}$ \\
\hline Angbaobé & $80.48 \pm 0.1^{\mathrm{A}}$ & $47.60 \pm 0.135^{\mathrm{jj}}$ & $11 \pm 1.0^{\mathrm{bcdf}}$ & $6.78 \pm 0.16^{\mathrm{hi}}$ & $251.94 \pm 0.58^{f}$ & $181.20 \pm 0.23^{\mathrm{g}}$ & $70.74 \pm 0.35^{\mathrm{e}}$ & $0.70 \pm 0.25^{\mathrm{a}}$ & $28.50 \pm 0.71^{o p}$ & $26.02 \pm 0.18^{\mathrm{sc}}$ & $116.70 \pm 2^{s}$ \\
\hline Anklouman & $45.27 \pm 0.57^{C}$ & $16.23 \pm 0.07^{\mathrm{rs}}$ & $8 \pm 0.6^{\mathrm{dejk}}$ & $0.47 \pm 0.23^{1}$ & $400.41 \pm 4.31^{\mathrm{a}}$ & $137.04 \pm 0.12^{\mathrm{m}}$ & $263.37 \pm 4.9^{\mathrm{a}}$ & $0.80 \pm 0.02^{\mathrm{a}}$ & $29 . \pm 7078^{\text {op }}$ & $28.13 \pm 0.56^{c}$ & $119.92 \pm 3^{q}$ \\
\hline Assina & $46.87 \pm 0.15^{\mathrm{C}}$ & $17 \pm 0.1^{\mathrm{rs}}$ & $4.32 \pm 0.5^{\mathrm{jklo}}$ & $3.85 \pm 0.57^{\mathrm{ikl}}$ & $199.46 \pm 3.71^{\mathrm{kl}}$ & $160.00 \pm 2.82^{j}$ & $39.46 \pm 0.83^{\mathrm{jk}}$ & $0.49 \pm 0.25^{\mathrm{a}}$ & $38.11 \pm 68^{\mathrm{fg}}$ & $9.80 \pm 0.20^{c}$ & $44.64 \pm 1^{\circ}$ \\
\hline Babétéi & $115.13 \pm 0.19^{v}$ & $97.28 \pm 0.59^{c}$ & $9 \pm 0.8^{\text {bcdi }}$ & $1 \pm 0.85^{\mathrm{kl}}$ & $219.03 \pm 1.54^{\mathrm{i}}$ & $186.64 \pm 0.91^{\mathrm{f}}$ & $32.39 \pm 0.3^{\operatorname{lm}}$ & $0.38 \pm 0.84^{\mathrm{a}}$ & $33.69 \pm 3.53^{b c}$ & $29.32 \pm 0.27^{c}$ & $125.74 \pm 2^{q}$ \\
\hline Bakarou & $458.07 \pm 0.57^{\mathrm{g}}$ & $38.85 \pm 2.26^{\mathrm{jkm}}$ & $11 \pm 1 b^{\mathrm{cdf}}$ & $11.71 \pm 0.12^{\mathrm{bcf}}$ & $170.47 \pm 1.10^{p}$ & $150.02 \pm 1.30^{\mathrm{k}}$ & $20.45 \pm 0.2^{\mathrm{op}}$ & $0.99 \pm 0.15^{\mathrm{a}}$ & $38.77 \pm 0.70^{\mathrm{ijk}}$ & $35.50 \pm 0.33^{\mathrm{c}}$ & $156.62 \pm 2^{1}$ \\
\hline Baniouré & $395.08 \pm 1.44^{1}$ & $48.63 \pm 1.51^{\mathrm{jj}}$ & $9.4 \pm 0.1^{\mathrm{bcdh}}$ & $9.73 \pm 0.12^{\mathrm{cdh}}$ & $145.25 \pm 0.44^{\mathrm{s}}$ & $122.72 \pm 0.52^{\mathrm{p}}$ & $22.53 \pm 0.08^{\circ}$ & $0.88 \pm 0.51^{\mathrm{a}}$ & $32.95 \pm 0.70^{\mathrm{op}}$ & $30.15 \pm 0.04^{d}$ & $132.98 \pm 1^{\circ}$ \\
\hline Bobotchinga & $28.60 \pm 0.94^{\mathrm{F}}$ & $21.00 \pm 0.15^{\text {oqr }}$ & $8 \pm 0.9^{\mathrm{dcjk}}$ & $13.36 \pm 0.27^{\mathrm{bc}}$ & $177.05 \pm 0.60^{\circ}$ & $131.57 \pm 0.72^{\mathrm{n}}$ & $17.5 \pm 0.12^{\mathrm{qr}}$ & $0.59 \pm 0.81^{\mathrm{a}}$ & $29.42 \pm 0.70^{\mathrm{bc}}$ & $26.69 \pm 0.38^{d}$ & $119.32 \pm 2^{\mathrm{g}}$ \\
\hline Boniakpa & $46.40 \pm 0.73^{\mathrm{C}}$ & $41.24 \pm 0.43^{\mathrm{jk}}$ & $11 \pm 1.8^{\mathrm{bcdf}}$ & $8.50 \pm 0.33^{\mathrm{fgh}}$ & $287.33 \pm 0.53^{\mathrm{e}}$ & $211.72 \pm 0.25^{d}$ & $75.61 \pm 0.28^{d}$ & $0.37 \pm 0.03^{\mathrm{a}}$ & $39.65 \pm 0.70^{\mathrm{bc}}$ & $37.33 \pm 0.36^{\mathrm{d}}$ & $162.62 \pm 3^{1}$ \\
\hline dambani & $466.32 \pm 0.7^{\mathrm{e}}$ & $31.32 \pm 0.75^{\mathrm{kop}}$ & $8.65 \pm 0.25^{\text {bcdi }}$ & $12.58 \pm 0.12^{\mathrm{bcd}}$ & $114.11 \pm 0.44^{\mathrm{A}}$ & $102.44 \pm 1.04^{t}$ & $11.67 \pm 0.6^{\mathrm{s}}$ & $0.73 \pm 0.14^{\mathrm{a}}$ & $40.08 \pm 0.70^{\text {hij }}$ & $37.22 \pm 0.45^{\text {de }}$ & $161.72 \pm 2^{q}$ \\
\hline Déba & $320.96 \pm 0.10^{\mathrm{n}}$ & $47.88 \pm 0.75^{\mathrm{jj}}$ & $12.55 \pm 0.2^{\mathrm{bc}}$ & $11.98 \pm 2.37^{\mathrm{bcf}}$ & $176.83 \pm 4.38^{\circ}$ & $120.6 \pm 0.52 p q$ & $56.19 \pm 3.86^{\mathrm{g}}$ & $0.9 \pm 0.61^{\mathrm{a}}$ & $31.80 \pm 0.71^{\mathrm{op}}$ & $28.44 . \pm 0.51^{\mathrm{ef}}$ & $129.87 \pm 0^{1}$ \\
\hline Djilaadja & $479.73 \pm 0.67^{c}$ & $39.60 \pm 3.01^{\mathrm{jkl}}$ & $5.8 \pm 0.2^{\mathrm{ghjn}}$ & $3.55 \pm 0.04^{\mathrm{ikl}}$ & $118.50 \pm 0.43^{\mathrm{z}}$ & $111.28 \pm 1.04^{\mathrm{s}}$ & $7.22 \pm 0.61^{t}$ & $0.91 \pm 0.45^{\mathrm{a}}$ & $29.12 \pm 0.70^{\mathrm{fg}}$ & $25.27 . \pm 0.03^{f}$ & $107.74 \pm 0^{\mathrm{q}}$ \\
\hline Dodo & $462.78 \pm 1.72^{f}$ & $59.92 \pm 3.76^{\mathrm{gh}}$ & $3 \pm 0.5^{\mathrm{mno}}$ & $9.41 \pm 0.20^{\mathrm{dgh}}$ & $67.41 \pm 0.22^{C}$ & $63.18 \pm 0.78^{t}$ & $4.23 \pm 0.56^{\mathrm{t}}$ & $0.66 \pm 0.05^{\mathrm{a}}$ & $35.38 \pm 0.70^{\mathrm{op}}$ & $34.07 \pm 0.53^{\mathrm{g}}$ & $142.78 \pm 2^{f}$ \\
\hline DrA21-2003 & $470.34 \pm 0.10^{\mathrm{d}}$ & $73.48 \pm 0.75^{f}$ & $3.5 \pm 0.45^{\mathrm{mn}}$ & $10.87 \pm 0.08^{\mathrm{bcg}}$ & $130.34 \pm 0.45^{\mathrm{wx}}$ & $111.80 \pm 0.52^{\mathrm{pq}}$ & $18.5 \pm 0.07^{\mathrm{op}}$ & $0.87 \pm 0.65^{\mathrm{a}}$ & $28.38 \pm 0.71^{\mathrm{a}}$ & $26.07 \pm 0.28^{\mathrm{gh}}$ & $111.79 \pm 0^{f}$ \\
\hline DrA39-2003 & $498.97 \pm 0.20^{\mathrm{a}}$ & $28.52 \pm 3.01^{\mathrm{mnp}}$ & $8.35 \pm 0.2^{\text {cdij }}$ & $9.61 \pm 0.31^{\mathrm{cdh}}$ & $192.62 \pm 0.48^{\mathrm{m}}$ & $150.54 \pm 0.26^{\mathrm{s}}$ & $42.08 \pm 0.22^{\mathrm{ij}}$ & $0.75 \pm 0.23^{\mathrm{a}}$ & $42.90 \pm 0.32^{o p}$ & $40.35 \pm 0.30^{\mathrm{h}}$ & $172.07 \pm 1^{\mathrm{m}}$ \\
\hline DrA5-2003 & $398.62 \pm 0.201$ & $31.32 \pm 2.26^{\mathrm{kop}}$ & $2.4 \pm 0.2^{\text {no }}$ & $12.42 \pm 0.28^{\text {bce }}$ & $369.58 \pm 0.22^{b}$ & $326.83 \pm 0.78^{w}$ & $42.67 \pm 0.56^{\mathrm{ij}}$ & $0.9 \pm 0.32^{\mathrm{a}}$ & $28.71 \pm 01^{\mathrm{def}}$ & $25.82 \pm 0.18^{h}$ & $110.44 \pm 1 t$ \\
\hline DrA65-2003 & $322.40 \pm 0.57^{\mathrm{n}}$ & $37.34 \pm 2.26^{\mathrm{klp}}$ & $3.4 \pm 0.1^{\mathrm{mno}}$ & $13.25 \pm 0.08^{\text {bcd }}$ & $150.08 \pm 0.43^{\mathrm{r}}$ & $116.48 \pm 2.08^{\mathrm{s}}$ & $33.6 \pm 1.65^{\operatorname{lm}}$ & $0.97 \pm 0.65^{\mathrm{a}}$ & $36.30 \pm 0.70^{\mathrm{klm}}$ & $33.66 \pm 0.46^{j}$ & $143.02 \pm 2^{\mathrm{jk}}$ \\
\hline Effourou & $203.93 \pm 0.38^{\mathrm{s}}$ & $23.79 \pm 3.76^{\mathrm{opq}}$ & $3.95 \pm 0.05^{\mathrm{kln}}$ & $11.43 \pm 0.24^{\mathrm{bcg}}$ & $111.92 \pm 0.88^{\mathrm{A}}$ & $90.48 \pm 0.52^{k}$ & $21.4 \pm 0.36^{\mathrm{op}}$ & $1.02 \pm 0.14^{\mathrm{a}}$ & $31.81 \pm 0.67^{\mathrm{op}}$ & $29.25 \pm 0.46^{\mathrm{j}}$ & $125.13 \pm 2^{t}$ \\
\hline Gaboubaba & $382.63 \pm 0.48^{\mathrm{m}}$ & $50.89 \pm 0.75^{j}$ & $1.7 \pm 0.1^{\circ}$ & $11.91 \pm 0.47^{\text {bcf }}$ & $124.86 \pm 0.66^{y}$ & $112.32 \pm 0.52^{\mathrm{a}}$ & $12.54 \pm 0.14^{\mathrm{rs}}$ & $0.76 \pm 0.85^{\mathrm{a}}$ & $29.73 \pm 0.71^{\mathrm{cd}}$ & $25.60 \pm 0.41^{\mathrm{ij}}$ & $108.73 \pm 2^{\mathrm{a}}$ \\
\hline Gnidou & $397.28 \pm 0.19^{1}$ & $48.63 \pm 3.01^{\mathrm{jj}}$ & $3.8 \pm 0.1^{1 \mathrm{mno}}$ & $10.87 \pm 0.55^{\mathrm{bcg}}$ & $156.44 \pm 0.22^{q}$ & $127.14 \pm 1.3^{\mathrm{qr}}$ & $29.3 \pm 1.08^{\mathrm{mn}}$ & $0.8 \pm 0.08^{\mathrm{a}}$ & $36.98 \pm 0.70^{\mathrm{ab}}$ & $34.71 \pm 0.50^{\mathrm{ij}}$ & $146.62 \pm 2^{t}$ \\
\hline
\end{tabular}


Int.J.Curr.Microbiol.App.Sci (2020) 9(3): 1663-1682

\begin{tabular}{|c|c|c|c|c|c|c|c|c|c|c|c|}
\hline Gominan & $479.38 \pm 1.72^{\mathrm{c}}$ & $51.64 \pm 4.52^{j}$ & $9.55 \pm 0.15^{\text {bcdh }}$ & $2.96 \pm 1.42^{\mathrm{jkl}}$ & $184.72 \pm 0.88^{\mathrm{n}}$ & $170.04 \pm 0.52^{v}$ & $14.68 \pm 0.36^{\mathrm{rs}}$ & $0.77 \pm 0.31^{\mathrm{a}}$ & $41.13 \pm 0.71^{\mathrm{ijk}}$ & $39.10 \pm 0.04^{\mathrm{ij}}$ & $166.21 \pm 1^{\mathrm{jk}}$ \\
\hline Hêapala & $95.45 \pm 0.57^{y}$ & $65.99 \pm 0.15^{\mathrm{gh}}$ & $9 \pm 1.0^{\text {bcdi }}$ & $2.07 \pm 0.33^{\mathrm{kl}}$ & $239.78 \pm 0.47^{\mathrm{g}}$ & $175.90 \pm 0.90^{\mathrm{s}}$ & $63.88 \pm 0.43^{f}$ & $0.55 \pm 0.84^{\mathrm{a}}$ & $30.13 \pm 0.69^{\mathrm{bc}}$ & $28.47 \pm 0.32^{\mathrm{jk}}$ & $122.8 \pm 2^{\mathrm{no}}$ \\
\hline Idoro & $474.94 \pm 5.65^{\mathrm{c}}$ & $24.54 \pm 1.50^{\mathrm{opq}}$ & $5 \pm 0.4^{\mathrm{ijno}}$ & $14.36 \pm 0.08^{b}$ & $139.33 \pm 0.21^{\mathrm{tu}}$ & $94.90 \pm 0.26^{\circ}$ & $44.43 \pm 0.05^{\mathrm{hi}}$ & $0.74 \pm 0.5^{\mathrm{a}}$ & $38.61 \pm 0.67 \mathrm{a}$ & $35.93 \pm 0.06^{\mathrm{kl}}$ & $153.98 \pm 0^{t}$ \\
\hline Kagourou & $423.23 \pm 2.39^{j}$ & $73.48 \pm 3.76 \mathrm{f}$ & $6.5 \pm 0.5^{\mathrm{fghm}}$ & $18.80 \pm 0.07^{\mathrm{a}}$ & $44.82 \pm 0.44^{\mathrm{E}}$ & $41.08 \pm 2.60^{j}$ & $3.74 \pm 2.16^{t}$ & $0.61 \pm 0.41^{\mathrm{a}}$ & $42.86 \pm 0.71^{\mathrm{j} k}$ & $39.72 \pm 0.04^{\mathrm{kl}}$ & $172.25 \pm 0^{\mathrm{ij}}$ \\
\hline Katala & $476.76 \pm 0.20^{c}$ & $26.80 \pm 3.76^{\text {noq }}$ & $9.5 \pm 0.2^{\text {bcdh }}$ & $13.05 \pm 0.51^{\mathrm{bcd}}$ & $140.88 \pm 2.19^{t}$ & $119.86 \pm 0.78^{\mathrm{h}}$ & $21.02 \pm 1.4^{\mathrm{op}}$ & $0.76 \pm 0.47^{\mathrm{a}}$ & $32.08 \pm 0.70^{\mathrm{mn}}$ & $27.06 \pm 0.05^{\mathrm{kl}}$ & $122.3 \pm 0^{\mathrm{bc}}$ \\
\hline Kpagninan & $260.03 \pm 0.76^{q}$ & $156.27 \pm 0.07^{\mathrm{a}}$ & $18 \pm 0.7^{\mathrm{a}}$ & $3.20 \pm 0.58^{\mathrm{jkl}}$ & $135.09 \pm 0.35^{\mathrm{uv}}$ & $116.75 \pm 0.42^{\mathrm{u}}$ & $18.34 \pm 0.7$ & $0.51 \pm 0.01^{\mathrm{a}}$ & $40.75 \pm 0.70^{\text {gh }}$ & $38.12 \pm 0.51^{\mathrm{kl}}$ & $169.1 \pm 3^{\mathrm{op}}$ \\
\hline Kpakara & $90.38 \pm 0.30^{z}$ & $55.90 \pm 0.3^{\mathrm{hi}}$ & $13 \pm 1.3^{b}$ & $3.73 \pm 0.30^{\mathrm{ikl}}$ & $289.90 \pm 0.33^{\text {de }}$ & $205.14 \pm 0.52^{y}$ & $84.76 \pm 0.19^{\mathrm{g}}$ & $0.72 \pm 0.11^{\mathrm{a}}$ & $29.59 \pm 56^{\mathrm{ijk}}$ & $25.19 \pm 0.32^{\mathrm{mn}}$ & $113.1 \pm 3^{\mathrm{h}}$ \\
\hline Kratchi & $194.16 \pm 1.72^{t}$ & $31.32 \pm 2.26^{\mathrm{kop}}$ & $8.7 \pm 0.2 \mathrm{dcbi}$ & $4.66 \pm 0.11^{\mathrm{ijk}}$ & $149.42 \pm 0.22^{r}$ & $146.38 \pm 0.78^{\mathrm{h}}$ & $3.04 \pm 0.56^{b}$ & $0.54 \pm 0.58^{\mathrm{a}}$ & $31.18 \pm 0.79^{\mathrm{a}}$ & $29.30 \pm 0.40^{\mathrm{mn}}$ & $126.1 \pm 1^{\mathrm{op}}$ \\
\hline Labôkô & $95.20 \pm 2.44^{y}$ & $80.33 \pm 1.47^{e}$ & $13 \pm 0.4^{b}$ & $9.72 \pm 05^{\mathrm{cdh}}$ & $292.78 \pm 0.66^{\mathrm{d}}$ & $91.60 \pm 0.44^{\mathrm{k}}$ & $201.18 \pm 0.2^{\mathrm{g}}$ & $0.47 \pm 0.48^{\mathrm{a}}$ & $33.94 \pm 4.24^{\mathrm{ab}}$ & $33.69 \pm 0.32^{\mathrm{mn}}$ & $150.38 \pm 2^{\mathrm{bc}}$ \\
\hline Môrôkorou & $62.61 \pm 0.67^{\mathrm{B}}$ & $54.85 \pm 0.15 \mathrm{hi}$ & $10 \pm 1.0^{\mathrm{bcdg}}$ & $4.29 \pm 0.54^{\mathrm{ijk}}$ & $209.41 \pm 0.68^{j}$ & $149.92 \pm 0.35^{\text {uv }}$ & $59.49 \pm 0.33^{\mathrm{g}}$ & $0.88 \pm 0.35^{\mathrm{a}}$ & $32.88 \pm 0.71^{\text {no }}$ & $30.51 \pm 0.0^{\mathrm{no}}$ & $133 \pm 1^{\text {st }}$ \\
\hline Paroyobou & $47.34 \pm 0.76^{\mathrm{C}}$ & $39.13 \pm 0.26^{\mathrm{jkm}}$ & $11 \pm 0.9^{\text {bcdf }}$ & $6.35 \pm 0.66^{\mathrm{hij}}$ & $196.91 \pm 0.63^{1}$ & $150.26 \pm 0.62^{k}$ & $46.65 \pm 0.01^{\mathrm{hi}}$ & $0.77 \pm 0.81^{\mathrm{a}}$ & $38.96 \pm 0.70^{\text {no }}$ & $36.45 \pm 0.33^{\mathrm{op}}$ & $158.26 \pm 2^{\mathrm{n}}$ \\
\hline Portchabim & $410.88 \pm 0.57^{j}$ & $34.33 \pm 2.26^{\mathrm{klo}}$ & $9 \pm 1^{\text {bcdi }}$ & $14.08 \pm 0.12^{b}$ & $159.73 \pm 0.44^{q}$ & $126.62 \pm 0.78^{k}$ & $33.1 \pm 0.34^{\mathrm{Im}}$ & $0.89 \pm 0.15^{\mathrm{a}}$ & $43.07 \pm 0.70^{\mathrm{jk}}$ & $39.87 \pm 0.33^{p q}$ & $173.22 \pm 2^{\mathrm{n}}$ \\
\hline Singor & $402.64 \pm 1.15^{\mathrm{k}}$ & $36.59 \pm 4.52^{\mathrm{kln}}$ & $7.6 \pm 0.3^{\text {defl }}$ & $17.25 \pm 0.12^{\mathrm{a}}$ & $159.73 \pm 0.44^{q}$ & $142.74 \pm 0.26^{\circ}$ & $16.9 \pm 0.18^{\mathrm{qr}}$ & $0.53 \pm 0.63^{\mathrm{a}}$ & $41.36 \pm 0.70^{p}$ & $38.34 \pm 0.46^{\mathrm{qr}}$ & $167.1 \pm 0.8^{\mathrm{i}}$ \\
\hline Tarayè & $315.02 \pm 0.10$ & $27.55 \pm 1.50^{\text {nop }}$ & $5.45 \pm 0.15^{\mathrm{hij}}$ & $8.74 \pm 0.24^{\mathrm{efh}}$ & $49.86 \pm 0.66^{\mathrm{D}}$ & 43.2 & 6.65 & $0.74 \pm 0.20^{\mathrm{a}}$ & $29.66 \pm 0.70^{\mathrm{n}}$ & $27.50 \pm 0.36^{\mathrm{st}}$ & $118.40 \pm 3^{\text {ef }}$ \\
\hline Tchée & $398.62 \pm 0.38^{1}$ & $28.31 \pm 0.75^{\mathrm{mnp}}$ & $7 \pm 1^{\text {efgm }}$ & $18.83 \pm 0.04^{\mathrm{a}}$ & $132.75 \pm 0.66^{\mathrm{vw}}$ & $99.06 \pm 0$. & $33.69 \pm 0$. & $0.1 \pm 0.0$ & $28.36 \pm 0.70^{\mathrm{ab}}$ & $25.07 \pm 0.43^{\mathrm{st}}$ & $114.14 \pm 3^{\mathrm{a}}$ \\
\hline Wété & $107.46 \pm 0.45^{\mathrm{w}}$ & $60.97 \pm 0.21^{\text {gh }}$ & $12 \pm 2.0^{\mathrm{bcd}}$ & $7.96 \pm 0.78^{\mathrm{gh}}$ & $200.86 \pm 0.09^{\mathrm{kl}}$ & $163.71 \pm 0.33^{j}$ & $37.15 \pm 0.24^{\mathrm{kl}}$ & $0.71 \pm 0.16^{\mathrm{a}}$ & $32.44 \pm 0.70^{\mathrm{ab}}$ & $29.73 \pm 0.08^{\mathrm{st}}$ & $132.92 \pm 2^{\mathrm{cd}}$ \\
\hline Wokiri & $141.03 \pm 0.38$ & $105.59 \pm 0.15^{\mathrm{b}}$ & $7 \pm 0.6^{\mathrm{efgm}}$ & $3.52 \pm 0.69^{\mathrm{ikl}}$ & $189.62 \pm 0.66^{\mathrm{m}}$ & $168.55 \pm 0.49^{j}$ & $21.07 \pm 0.17^{\mathrm{p}}$ & $0.58 \pm 0.33^{\mathrm{a}}$ & $28.24 \pm 1.41^{\mathrm{n}}$ & $23.10 \pm 0.05^{\mathrm{st}}$ & $100.14 \pm 1^{1}$ \\
\hline Wokourou & $495.14 \pm 0.19^{b}$ & $111.12 \pm 2.2^{\mathrm{b}}$ & $10.6 \pm 0.3^{\mathrm{bcd} f}$ & $8.26 \pm 0.08^{\text {fgh }}$ & $127.05 \pm 0.20^{x y}$ & $93.60 \pm 1.04^{\mathrm{uv}}$ & $33.45 \pm 0.8^{\mathrm{Im}}$ & $0.82 \pm 0.04^{\mathrm{a}}$ & $39.82 \pm 0.70^{\mathrm{kl}}$ & $37.11 \pm 0.59^{\mathrm{tu}}$ & $161.30 \pm 2^{\mathrm{u}}$ \\
\hline Wouroutani & $83.84 \pm 1.21^{\mathrm{A}}$ & $47.81 \pm 0.61^{\mathrm{jj}}$ & $11 \pm 1.3^{\mathrm{bcdf}}$ & $1.83 \pm 0.47^{\mathrm{kl}}$ & $124.10 \pm 0.44^{y}$ & $112.55 \pm 0.66^{\mathrm{s}}$ & $11.55 \pm 0.22^{\mathrm{s}}$ & $0.72 \pm 0.37^{\mathrm{a}}$ & $28.39 \pm 0.70^{\mathrm{a}}$ & $26.38 \pm 0.06^{\mathrm{tu}}$ & $116.18 \pm 1^{\text {ef }}$ \\
\hline Yaassi & $320.39 \pm 0.09$ & $89.29 \pm 3.01^{\mathrm{d}}$ & $6 \pm 2^{\text {ghjn }}$ & $13.41 \pm 0.16^{\mathrm{bc}}$ & $138.67 \pm 0.44^{t}$ & $117.26 \pm 0.26^{\mathrm{qr}}$ & $21.41 \pm 0.8^{\mathrm{op}}$ & $0.82 \pm 0.06^{\mathrm{a}}$ & $41.22 \pm 0.71^{\mathrm{a}}$ & $38.45 \pm 0.31^{\text {tu }}$ & $164.60 \pm 2^{\mathrm{rs}}$ \\
\hline Yakounougo & $101.48 \pm 0.86^{x}$ & $61.02 \pm 0.15^{\mathrm{gh}}$ & $11 \pm 0.7^{\text {bcdf }}$ & $2.50 \pm 0.30^{\mathrm{kl}}$ & $333.77 \pm 0.53^{b}$ & $285.16 \pm 1.15^{\mathrm{b}}$ & $48.61 \pm 0.62^{h}$ & $0.45 \pm 0.35^{\mathrm{a}}$ & $40.43 \pm 69^{\mathrm{a}}$ & $38.63 \pm 0.35^{\mathrm{u}}$ & $165.42 \pm 2^{\mathrm{de}}$ \\
\hline Yonouan & $40.10 \pm 0.77^{\mathrm{D}}$ & $31.29 \pm 0.22^{\mathrm{kop}}$ & $8 \pm 0.4^{\mathrm{dcjk}}$ & $2.57 \pm 0.72^{\mathrm{jkl}}$ & $293.41 \pm 0.47^{\mathrm{d}}$ & $248.41 \pm 2.37^{c}$ & $45 \pm 1.9^{\mathrm{hi}}$ & $0.56 \pm 0.59 \mathrm{a}$ & $30.44 \pm 0.70^{\mathrm{ab}}$ & $28.82 \pm 0.28^{v}$ & $123.52 \pm 2^{\text {cd }}$ \\
\hline Zambè & $292.90 \pm 0.20^{p}$ & $68.21 \pm 1.51^{\mathrm{fg}}$ & $3.7 \pm 0.5^{\mathrm{jmno}}$ & $1.38 \pm 0.08^{\mathrm{kl}}$ & $140.65 \pm 1.97^{t}$ & $126.36 \pm 0.52^{\circ}$ & $14.29 \pm 1.45^{\mathrm{rs}}$ & $0.77 \pm 0.85 \mathrm{a}$ & $32.13 \pm 0.70^{\mathrm{n}}$ & $30.85 \pm 0.41^{\mathrm{w}}$ & $127.29 \pm 3^{\mathrm{mn}}$ \\
\hline
\end{tabular}

Means followed by different letters within the same column are significantly different at 0.05 level 
Table.3 Variability of the sugar and proximate compositions of the different Yam (Dioscorea rotundata) cultivars studied

\begin{tabular}{|l|l|l|l|l|l|l|l|}
\hline Variable & Maximum & Minimum & Mean & SE Mean & Median & SD & CV \\
\hline Total sugar (mg/g) & 499 & 28.6 & 269.3 & 24.5 & 304 & 170 & 63.14 \\
\hline $\begin{array}{l}\text { Reducing sugar } \\
\text { (mg/g) }\end{array}$ & 156.27 & 12.5 & 47.74 & 4.04 & 39.37 & 27.98 & 58.61 \\
\hline Fat (m/g) & 18 & 1.7 & 8.29 & 0.49 & 8.8 & 3.41 & 41.1 \\
\hline Proteins (mg/g) & 19.31 & 0.47 & 8.87 & 0.73 & 9.51 & 5.07 & 57.23 \\
\hline Starch (mg/g) & 400 & 44.8 & 178.6 & 11 & 158.9 & 76.5 & 42.85 \\
\hline Amylose (mg/g) & 326.83 & 17.5 & 135.88 & 8.3 & 126.49 & 57.5 & 42.31 \\
\hline Amylopectin (mg/g) & 263.37 & 3.04 & 40.04 & 6.54 & 31.98 & 45.33 & 113.21 \\
\hline Dry matter (\%) & 43.07 & 11.11 & 33.56 & 0.38 & 32.66 & 6.12 & 14.57 \\
\hline Ash (\%) & 1.11 & 0.37 & 0.72 & 0.02 & 0.74 & 0.16 & 23.14 \\
\hline Carbohydrate (\%) & 40.35 & 9.80 & 31.07 & 0.86 & 29.94 & 5.92 & 8.27 \\
\hline Energy (\%) & 174.17 & 45.27 & 136.01 & 3.65 & 135.35 & 25.31 & 16.75 \\
\hline
\end{tabular}

$\mathrm{SE}=$ Standard Error, $\mathrm{SD}=$ Standard Deviation, $\mathrm{CV}=$ Coefficient of Variation

Table.4 Pearson correlations of proximal parameters

\begin{tabular}{|l|c|c|c|c|c|c|c|c|}
\hline & $\begin{array}{c}\text { Total } \\
\text { Sugar }\end{array}$ & Rs & Lipid & Protein & Starch & Amylose & Amylopectin & $\begin{array}{c}\text { Dry } \\
\text { matter }\end{array}$ \\
\hline $\begin{array}{l}\text { Reducing } \\
\text { Sugar }\end{array}$ & 0.00 & & & & & & & \\
\hline Lipid & -0.36 & 0.29 & & & & & & \\
\hline Protein & 0.42 & -0.29 & $0.21^{*}$ & & & & \\
\hline Starch & -0.55 & $-0.07^{*}$ & $0.28^{*}$ & -0.39 & & & & \\
\hline Amylose & -0.31 & 0.05 & $0.18^{*}$ & -0.39 & 0.77 & & & \\
\hline Amylopectin & -0.45 & $-0.12^{*}$ & $0.25^{*}$ & $-0.23^{*}$ & -0.71 & $0.16^{*}$ & & \\
\hline Dry matter & 0.815 & - & - & 0.528 & -0.48 & -0.309 & -0.352 & \\
\hline Ash & 0.52 & -0.26 & -0.29 & $0.18^{*}$ & $-0.27 *$ & 0.21 & $-0.14^{*}$ & 0.51 \\
\hline Carbohydrates & 0.80 & $-0.08^{*}$ & -0.34 & 0.51 & -0.47 & -0.31 & -0.35 & $0.99^{*}$ \\
\hline
\end{tabular}

$*$ Significant correlation Rs =Reducing sugar 
Table.5 Characteristics of the different cultivar groups obtained

\begin{tabular}{|c|c|c|}
\hline Groups & Cultivars & Characteristics \\
\hline Group 1 & $\begin{array}{l}\text { Yakanougo, Yonouan, Kpakara, Anklouman, } \\
\text { Labôkô, Boniakpa }\end{array}$ & $\begin{array}{l}\text { High content of starch, ash, } \\
\text { lipid, sugar, carbohydrates and } \\
\text { dry matter } \\
\text { - Less rich in protein }\end{array}$ \\
\hline Group 2 & $\begin{array}{l}\text { Kpouna, Angbaobé, Haakpala, Wété, Babété, } \\
\text { Wokiri, Wouroutani, Assina, Bobotchinga, } \\
\text { Sossouka, Morokorou, Paroyobou, Kratchi, } \\
\text { Ahimon, Effourou, Kpagninan, Deba, DrA65- } \\
\text { 2003, Yaassi, Zambè }\end{array}$ & $\begin{array}{l}\text { - Starches containing low levels } \\
\text { of amylopectins } \\
\text { - Rich in dry matter, reducing } \\
\text { sugars, and lipids } \\
\text { - Very poor in ash proteins }\end{array}$ \\
\hline Group 3 & $\begin{array}{l}\text { Portchabim, Gominan, kagourou, Amoula, } \\
\text { Adaani, Djilaadja, DrA 39-2003, DrA5-2003, } \\
\text { DrA21-2003, Gaboubaba, Gnidou, Idoro, } \\
\text { Katala, Singor, Dodo, Tchée, Wokourou, } \\
\text { Dambani, Baniouré, }\end{array}$ & $\begin{array}{l}\text { - Very rich in total sugar, } \\
\text { carbohydrates of dry matter, ash } \\
\text { and protein } \\
\text { - Less rich in starch and } \\
\text { amylopectin }\end{array}$ \\
\hline
\end{tabular}

Table.6 Mineral composition of different cultivars evaluated

\begin{tabular}{|l|l|l|l|l|l|l|l|l|}
\hline Cultivars & $\mathbf{F e}$ & $\mathbf{Z n}$ & $\mathbf{I}$ & $\mathbf{C a}$ & $\mathbf{M g}$ & $\mathbf{C a} / \mathbf{P}$ & $\mathbf{C a} / \mathbf{M g}$ \\
\hline Babèté & $8.45 \pm 0.3$ & $9.53 \pm 1.7$ & $2.77 \pm 1.2$ & $41.17 \pm 1$ & $292.83 \pm 1$ & $486.28 \pm 0.8$ & $7.11 \pm 2.4$ & $0.60 \pm 0.7$ \\
\hline Labôkô & $9.92 \pm 0.11$ & $12.82 \pm 2.9$ & $2.62 \pm 2.1$ & $13.07 \pm 3$ & $356.57 \pm 2$ & $297.31 \pm 0.6$ & $27.26 \pm 2.7$ & $1.11 \pm 1$ \\
\hline Bobotchinga & $9.49 \pm 0.4$ & $2.27 \pm 0.3$ & $2.37 \pm 0.3$ & $37.50 \pm 1$ & $304.62 \pm 2$ & $131.33 \pm 1$ & $8.12 \pm 0.7$ & $2.31 \pm 2$ \\
\hline Assina & $9.91 \pm 0.2$ & $3.93 \pm 0.09$ & $2.17 \pm 0.8$ & $27.30 \pm 0.1$ & $341.33 \pm 2$ & $260.43 \pm 3$ & $12.49 \pm 2.5$ & $1.31 \pm 0.5$ \\
\hline Héapala & $7.67 \pm 0.4$ & $1.81 \pm 9.5$ & $1.94 \pm 0.7$ & $29.57 \pm 0.7$ & $144.61 \pm 2$ & $560.78 \pm 0.2$ & $4.89 \pm 2.4$ & $0.25 \pm 0.6$ \\
\hline Soussouka & $11.11 \pm 0.7$ & $8.56 \pm 0.2$ & $1.65 \pm 0.4$ & $71.99 \pm 0.5$ & $239.68 \pm 2$ & $699.63 \pm 0.3$ & $3.32 \pm 1.9$ & $0.34 \pm 0.4$ \\
\hline Anklouman & $6.49 \pm 0.12$ & $2.51 \pm 0.4$ & $0.57 \pm 0.1$ & $25.15 \pm 0.5$ & $409.30 \pm 4$. & $1399.94 \pm 3$ & $16.27 \pm 2$ & $0.29 \pm 3$ \\
\hline Yakanougou & $8.84 \pm 0.2$ & $1.40 \pm 0.6$ & $1.01 \pm 0.6$ & $24.8 \pm 0.5$ & $26.36 \pm 2$ & $1119.96 \pm 3$ & $10.70 \pm 3$ & $0.23 \pm 3.7$ \\
\hline Kpagnina & $12.27 \pm 0.8$ & $4.44 \pm 0.3$ & $4.12 \pm 0.7$ & $20.54 \pm 0.1$ & $292.64 \pm 1$ & $329.56 \pm 0.1$ & $14.24 \pm 0.9$ & $0.88 \pm 3.4$ \\
\hline Angbaobé & $9.80 \pm 0.5$ & $6.52 \pm 0.8$ & $2.52 \pm 0.2$ & $39.36 \pm 0.2$ & $556.85 \pm 3.4$ & $725.04 \pm 1$ & $14.13 \pm 0.8$ & $0.76 \pm 3.6$ \\
\hline Morôkôrou & $10.98 \pm 0.8$ & $5.98 \pm 1.6$ & $3.46 \pm 0.1$ & $28.73 \pm 0.3$ & $336.842 \pm 2$ & $1630.77 \pm 1$ & $11.72 \pm 0.5$ & $0.20 \pm 1.8$ \\
\hline Kpouna & $9.10 \pm 0.01$ & $1.77 \pm 3.1$ & $2.82 \pm 2$ & $54.6 \pm 0.7$ & $494.81 \pm 1$ & $378.68 \pm 0.2$ & $9.06 \pm 0.5$ & $1.30 \pm 0.5$ \\
\hline Wétè & $12.66 \pm 0.9$ & $12.06 \pm 1.8$ & $1.27 \pm 3$ & $33.51 \pm 0.2$ & $476.66 \pm 1$ & $672.73 \pm 2.1$ & $14.22 \pm 3.5$ & $0.70 \pm 0.9$ \\
\hline Wouroutani & $11.13 \pm 0.2$ & $0.55 \pm 0.3$ & $0.62 \pm 1$ & $32.25 \pm 0.1$ & $349.90 \pm 1$ & $825.51 \pm 3.1$ & $10.84 \pm 1.4$ & $0.42 \pm 0.6$ \\
\hline Kpakara & $10.32 \pm 0.1$ & $4.45 \pm 0.1$ & $0.82 \pm 0.8$ & $33.49 \pm 0.9$ & $264.63 \pm 2$ & $738.42 \pm 0.4$ & $7.90 \pm 1.4$ & $0.35 \pm 0.5$ \\
\hline Paroyoubou & $11.11 \pm 1$ & $4.05 \pm 0.8$ & $0.59 \pm 2.6$ & $25.99 \pm 1.9$ & $485.88 \pm 3$ & $470.42 \pm 0.6$ & $18.69 \pm 1.9$ & $1.03 \pm 0.4$ \\
\hline yonouan & $8.22 \pm 3$ & $7.55 \pm 0.2$ & $0.37 \pm 1.4$ & $52.94 \pm 1.6$ & $560 \pm 1.2$ & $616.63 \pm 1.3$ & $10.57 \pm 1.2$ & $0.90 \pm 2.3$ \\
\hline Boniakpa & $13.65 \pm 0.2$ & $9.61 \pm 0.7$ & $0.29 \pm 1.0$ & $17.41 \pm 1.4$ & $303.71 \pm 1$ & $371.76 \pm 2.3$ & $17.44 \pm 0.2$ & $0.81 \pm 0.8$ \\
\hline Wôkiri & $6.37 \pm 0.1$ & $3.34 \pm 0.1$ & $3.51 \pm 5.1$ & $33.47 \pm 1.3$ & $420.74 \pm 1$ & $1230.16 \pm 0.6$ & $12.56 \pm 0.3$ & $0.34 \pm 1.9$ \\
\hline
\end{tabular}


Int.J.Curr.Microbiol.App.Sci (2020) 9(3): 1663-1682

\begin{tabular}{|c|c|c|c|c|c|c|c|c|}
\hline Adani & $33.45 \pm 3$ & $11.95 \pm 0.1$ & $1.58 \pm 1.2$ & $62.45 \pm 1.2$ & $62.45 \pm 1$ & $17.99 \pm 0.9$ & $1 \pm 0.5$ & $3.47 \pm 3.3$ \\
\hline Ahimon & $2.11 \pm 2$ & $11.90 \pm 0.2$ & $0.46 \pm 1.2$ & $475 \pm 1$ & $43.07 \pm 1$ & $68.87 \pm 0.7$ & $0.90 \pm 0.7$ & $0.62 \pm 2$ \\
\hline Alssoura & $6.55 \pm 0.9$ & $14.53 \pm 0.5$ & $1.33 \pm 4.6$ & $73.72 \pm 1.2$ & $75.61 \pm 1$ & $45.74 \pm 0.3$ & $1.02 \pm 0.8$ & $1.51 \pm 7$ \\
\hline Amoula & $8.06 \pm 1.2$ & $11.25 \pm 0.1$ & $1.64 \pm 0.1$ & $72.65 \pm 0.4$ & $56.25 \pm 1$ & $24.57 \pm 0.2$ & $0.77 \pm 0.5$ & $1.65 \pm 2.7$ \\
\hline Bakarou & $1.79 \pm 0.4$ & $10.13 \pm 0.3$ & $0.45 \pm 0.1$ & $152.48 \pm 0.4$ & $12.21 \pm 3$ & $3.69 \pm 0.1$ & $0.08 \pm 0.6$ & $3.30 \pm 3.9$ \\
\hline Baniouré & $4.87 \pm 2.4$ & $8.32 \pm 0.1$ & $0.98 \pm 0.5$ & $83.23 \pm 0.5$ & $24.95 \pm 1$ & $16.98 \pm 3$ & $0.29 \pm 0.9$ & $1.4 \pm 2.4$ \\
\hline Dambani & $7.26 \pm 0.4$ & $10.07 \pm 0.1$ & $2.19 \pm 0.6$ & $41.18 \pm 0.5$ & $33.716 \pm 1$ & $12.98 \pm 0.2$ & $0.81 \pm-.8$ & $2.59 \pm 0.5$ \\
\hline Déba & $6.80 \pm 0.02$ & $6.02 \pm 0.4$ & $0.21 \pm 0.7$ & $44.98 \pm 0.2$ & $44.60 \pm 2$ & $1.79 \pm 0.1$ & $0.99 \pm 0.4$ & $24.79 \pm 0.6$ \\
\hline Djiladja & $6.16 \pm 0.1$ & $7.40 \pm 0.1$ & $1.02 \pm 0.4$ & $51.41 \pm 2.7$ & $25.44 \pm 0.2$ & $15.39 \pm 1$ & $0.49 \pm 3.1$ & $6.1 \pm 55$ \\
\hline $\mathrm{D}_{\mathrm{r}} \mathrm{A}_{21}-2003$ & $3.93 \pm 1.8$ & $5.22 \pm 1.3$ & $1.80 \pm 0.3$ & $66.91 \pm 2.3$ & $32.35 \pm 0.8$ & $21.35 \pm 0.5$ & $0.48 \pm 2.1$ & $1.51 \pm 2.9$ \\
\hline $\mathrm{DrA}_{39^{-}}-2003$ & $5.19 \pm 1.4$ & $7.65 \pm 1.4$ & $0.98 \pm 0.1$ & $57.53 \pm 2$ & $60.317 \pm 0.2$ & $36.49 \pm 3.2$ & $1.04 \pm 1$ & $1.65 \pm 3.2$ \\
\hline $\mathrm{DrA}_{5}-2003$ & $4.86 \pm 1.4$ & $5.38 \pm 2.4$ & $1.82 \pm 0.7$ & $63.11 \pm 1$ & $57.79 \pm 0.2$ & $1.84 \pm 2.6$ & $0.91 \pm 0$ & 31. $40 \pm 2$ \\
\hline $\mathrm{DrA}_{65}-2003$ & $3.97 \pm 3.1$ & $4.23 \pm 4.5$ & $2.37 \pm 0.6$ & $60.54 \pm 1$ & $46.25 \pm 0.3$ & $1.64 \pm 2.1$ & $0.76 \pm 0.5$ & $28.10 \pm 1$ \\
\hline Effourou & $10.12 \pm 0.05$ & $7.97 \pm 3.2$ & $1.31 \pm 0.4$ & $52.33 \pm 2$ & $24.87 \pm 3.1$ & $28.42 \pm 0.1$ & $0.47 \pm 0.8$ & $0.87 \pm 0.5$ \\
\hline Gaboubaba & $5.88 \pm 0.01$ & $2.91 \pm 0.1$ & $1.53 \pm 3$ & $40.03 \pm 3$ & $73.56 \pm 0.3$ & $1.85 \pm 0.2$ & $1.83 \pm 0.3$ & $39.67 \pm 1$ \\
\hline Gnidou & $6.51 \pm 0.6$ & $5.30 \pm 0.1$ & $3.78 \pm 1$ & $40.53 \pm 3$ & $57.57 \pm 0.8$ & $14.66 \pm 0.6$ & $1.42 \pm 0.4$ & $3.92 \pm 0.8$ \\
\hline Idoro & $7.81 \pm 0.6$ & $5.96 \pm 0.2$ & $1.52 \pm 1$ & $51.07 \pm 1$ & $31.54 \pm 0.3$ & $36.43 \pm 0.7$ & $0.62 \pm 0.7$ & $8.86 \pm 2$ \\
\hline Gominan & $7.52 \pm 0.7$ & $5.59 \pm 0.8$ & $2.11 \pm 1$ & 57.382 & $61.99 \pm 1$ & $7.14 \pm 0.7$ & $1.08 \pm 2$ & $8.67 \pm 1$ \\
\hline Kagourou & $6.35 \pm 0.4$ & $7.83 \pm 0.7$ & $1.53 \pm 1.5$ & $32.14 \pm 202$ & $31.42 \pm 2$ & $12.1 \pm 0.7$ & $0.9 \pm 0.4$ & $2.59 \pm 0.4$ \\
\hline Katala & $8.52 \pm 1$ & $4.98 \pm 0.5$ & $3.02 \pm 0.5$ & $54.9 \pm 2$ & $16.84 \pm 3$ & $8.49 \pm 0.7$ & $0.30 \pm 0.6$ & $1.98 \pm 0.6$ \\
\hline Krachi & $7.95 \pm 2$ & $3.86 \pm 2.9$ & $5.68 \pm 0.7$ & $60.71 \pm 0.3$ & $31.74 \pm 1$ & $13.44 \pm 0.4$ & $0.53 \pm 0.2$ & $2.37 \pm 0.7$ \\
\hline Portchabim & $5.84 \pm 08$ & $15.15 \pm 1.8$ & $2.21 \pm 0.8$ & $90.77 \pm 0.6$ & $26.03 \pm 2$ & $10.50 \pm 20$ & $0.28 \pm 0.6$ & $2.47 \pm 0.8$ \\
\hline Singor & $5.21 \pm 0.3$ & $4.72 \pm 0.7$ & $1.53 \pm 0.4$ & $78.77 \pm 0.6$ & $15.29 \pm 0.8$ & $12.95 \pm 1$ & $0.19 \pm 0.7$ & $1.18 \pm 3$ \\
\hline dodo & $7.59 \pm 0.6$ & $7.08 \pm 0.8$ & $4.97 \pm 0.3$ & $40.42 \pm 0.7$ & $43.75 \pm 0.3$ & $17.01 \pm 3.4$ & $1.08 \pm 1$ & $2.57 \pm 2.4$ \\
\hline Tchée & $10.47 \pm 0.7$ & $12.93 \pm 0.2$ & $2.88 \pm 2.4$ & $91.98 \pm 2.8$ & $48.85 \pm 1$ & $11.08 \pm 3.5$ & $0.53 \pm 2$ & $4.40 \pm 1.5$ \\
\hline Tarä & $4.04 \pm 0.6$ & $20.03 \pm 0.3$ & $3.39 \pm 2.1$ & $68.58 \pm 1.9$ & $39.84 \pm 3$ & $24.10 \pm 21.71$ & $0.58 \pm 3$ & $1.65 \pm 2.5$ \\
\hline Wokourou & $10.26 \pm 0.5$ & $9.12 \pm 0.4$ & $2.68 \pm 2.3$ & $72.8 \pm 3.2$ & $67.2 \pm 4$ & $19.36 \pm 0.7$ & $0.92 \pm 1.3$ & $3.47 \pm 0.23$ \\
\hline Yassi & $22.6 \pm 0.6$ & $4.04 \pm 0.6$ & $5.26 \pm 2$ & $96.8 \pm 0.9$ & $19.2 \pm 12.3$ & $29.04 \pm 0.5$ & $0.19 \pm 0.6$ & $0.66 \pm 0.1$ \\
\hline Zembè & $6.67 \pm 3.5$ & $2.44 \pm 0.4$ & $3.98 \pm 0.3$ & $39.72 \pm 0.4$ & $62.62 \pm 1.2$ & $28.41 \pm 0.3$ & $1.56 \pm 0.7$ & $2.2 \pm 1.9$ \\
\hline
\end{tabular}


Table.7 Variability of mineral composition of different yam D. rotundata cultivars

\begin{tabular}{|l|l|l|l|l|l|l|l|}
\hline Variable & Maximum & Minimum & Mean & SE Mean & Median & SD & CV \\
\hline Iron & 22.6 & 1.794 & 8.16 & 0.49 & 7.81 & 3.39 & 41.54 \\
\hline $\mathrm{Zn}$ & 20.03 & 0.55 & 6.92 & 0.59 & 5.98 & 4.10 & 59.29 \\
\hline CI per I & 5.68 & 0.218 & 2.11 & 0.19 & 1.82 & 1.32 & 62.43 \\
\hline $\mathrm{P}$ & 152.48 & 13.08 & 51.96 & 3.73 & 51.08 & 25.58 & 49.23 \\
\hline $\mathrm{Ca}$ & 560 & 12.2 & 171.9 & 25.5 & 62.5 & 174.5 & 101.5 \\
\hline $\mathrm{Mg}^{2+}$ per Mg & 1630.8 & 1.65 & 285.5 & 60.7 & 28.4 & 416.4 & 145.83 \\
\hline
\end{tabular}

$\mathrm{SE}=$ Standard Error, $\mathrm{SD}=$ Standard Deviation and CV =Coefficient of Variation

Table.8 Characteristics of the different cultivar Groups formed based on mineral compositions

\begin{tabular}{|c|c|c|c|c|}
\hline Groups & variables & Min & Maxi & Medium \\
\hline \multirow[t]{6}{*}{ G1 } & Zinc per Zn & 0.340 & 13.12 & $5.65 \pm 3.61^{\mathrm{a}}$ \\
\hline & $\mathbf{P}$ & 12.77 & 72.99 & $34.33 \pm 14.04^{\mathrm{a}}$ \\
\hline & $\mathbf{C a}$ & 143.71 & 560.02 & $368.39 \pm 112.42^{a}$ \\
\hline & Mg & 130.73 & 1630.78 & $656.94 \pm 398^{a}$ \\
\hline & $\mathbf{C a} / \mathbf{P}$ & 3.21 & 27.37 & $12.26 \pm 5.51^{\mathrm{a}}$ \\
\hline & $\mathrm{Ca} / \mathrm{Mg}$ & 0.10 & 2.41 & $0.77 \pm 0.52^{\mathrm{a}}$ \\
\hline \multirow[t]{6}{*}{ G2 } & Zinc & 0.602 & 20.63 & $6.88 \pm 5.71^{b}$ \\
\hline & $\mathbf{P}$ & 24.00 & 96.95 & $55.10 \pm 19.75^{b}$ \\
\hline & $\mathbf{C a}$ & 19.50 & 265.54 & $64.17 \pm 74.23^{b}$ \\
\hline & Mg & 1.41 & 1120.51 & $146.13 \pm 354.63^{b}$ \\
\hline & $\mathbf{C a} / \mathbf{P}$ & 0.08 & 10.81 & $1.85 \pm 3.24^{\mathrm{b}}$ \\
\hline & $\mathrm{Ca} / \mathrm{Mg}$ & 0.13 & 28.20 & $6.83 \pm 10.84^{b}$ \\
\hline \multirow[t]{6}{*}{ G3 } & zinc & 1.91 & 16.17 & $8.26 \pm 3.39^{\mathrm{ab}}$ \\
\hline & $\mathbf{P}$ & 32.03 & 153.50 & $65.50 \pm 25.98^{\mathrm{ab}}$ \\
\hline & $\mathbf{C a}$ & 12.19 & 76.21 & $43.57 \pm 19.81^{\mathrm{ab}}$ \\
\hline & Mg & 0.85 & 78.00 & $18.28 \pm 14.64^{c}$ \\
\hline & $\mathrm{Ca} / \mathbf{P}$ & 0.03 & 1.947 & $0.76 \pm 0.44^{c}$ \\
\hline & $\mathrm{Ca} / \mathrm{Mg}$ & 1.08 & 39.77 & $6.18 \pm 9.94^{\mathrm{c}}$ \\
\hline
\end{tabular}




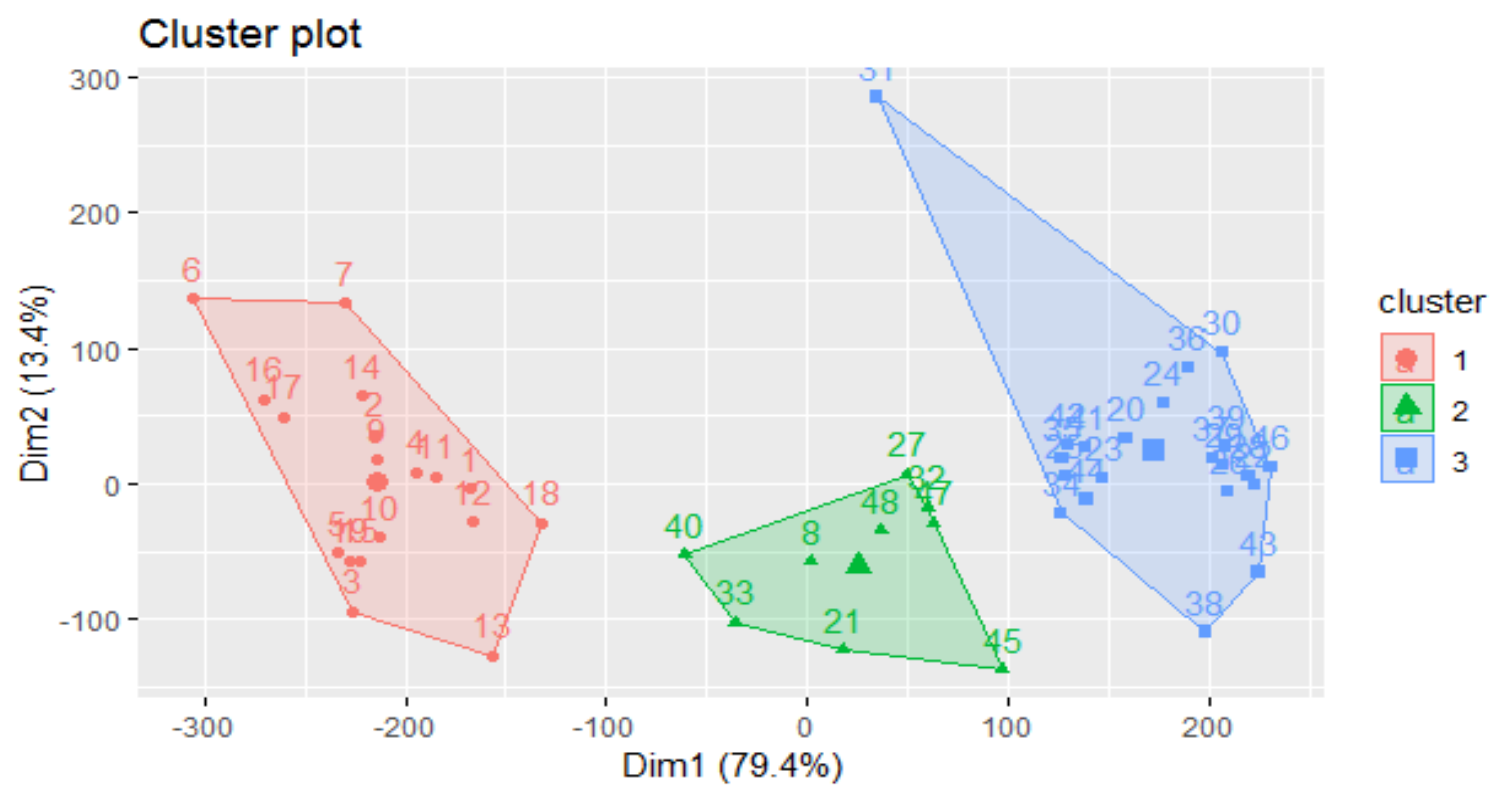

Figure.1 Projection of the cultivars on the plan defined by the two first axes of Principal Component analysis

\section{Cluster Dendrogram}

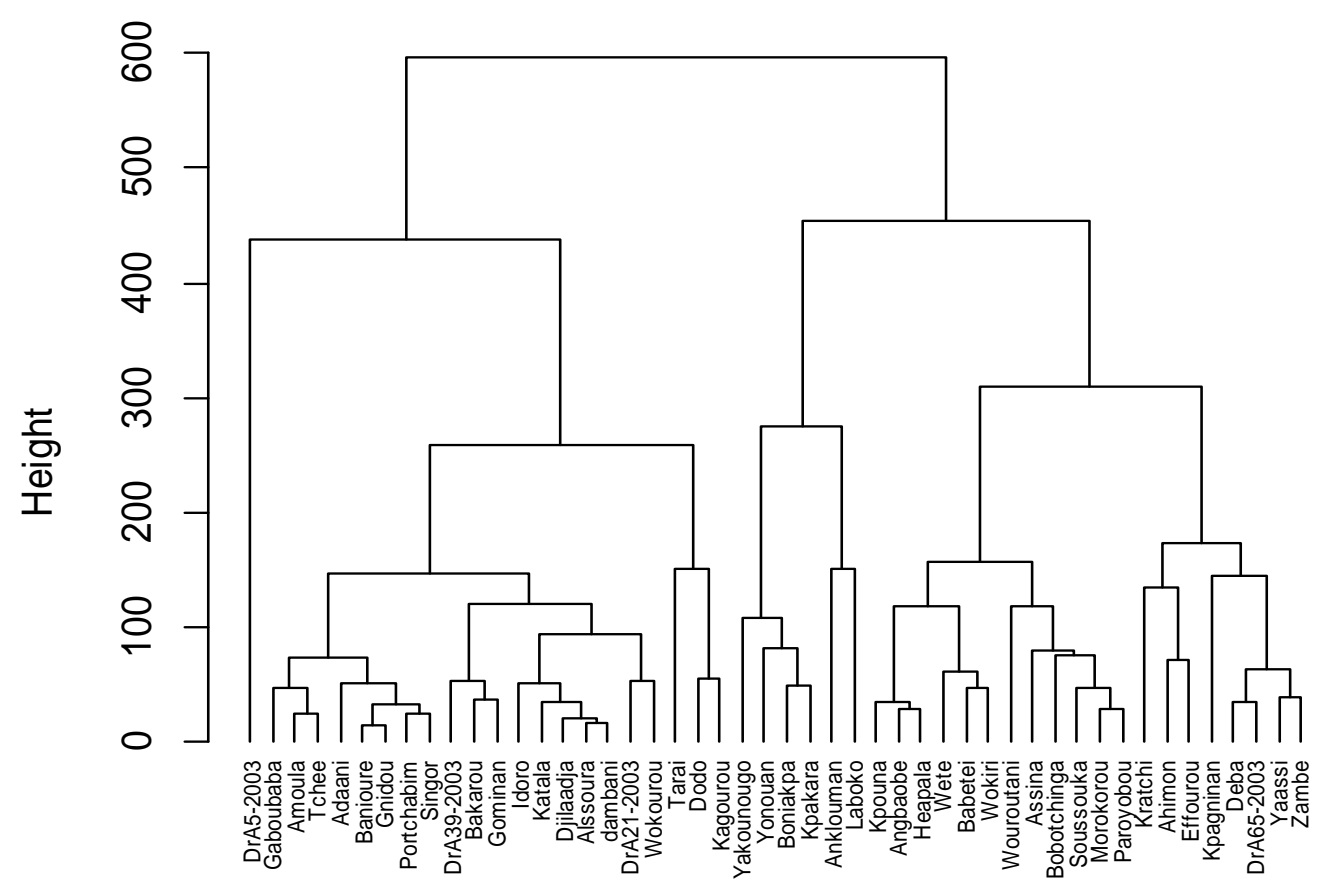

Figure.2 Dendrogram showing hierarchical classification of cultivars according to their sugar and proximate compositions 
These cultivars could present not only good textural characteristics but also good processing aptitude and good taste, due their high levels of lipids and dry matter. Akissoe et al., (2001) and Sanoussi et al., (2015) reported that lipids improve the taste of food. Group 2 cultivars (characterized by low levels of amylose, but rich in dry matter, reducing sugar, and lipids) will also be of interest for their involvement in hard-textured pastry production, such as appetizers. The peculiarity of the G1 cultivars is that they are used in the preparation of elastic pastes, which will not allow us obtain a light dough, instead a hard dough is obtained. This is a potential asset for their swelling and profitability, after adding water as reported by Mestre et al., (1996). Group 3 cultivars (which are rich in total sugar, carbohydrates, dry matter, ash and protein), characteristics are quite interesting, because not only they can provide good yielding finished products, they can also provide nutrients and can be used to combat malnutrition, because of their high protein and ash levels, so they can therefore be involved in the production of infant formula.

For breeding programme oriented towards the improvement of Magnesium, Calcium, starch, ash, lipids content, cultivars of Group 1 would be recommended. On the other hand, cultivars of Group 3 will be more applicable for a program which objective are to improve the content of phosphate, Zinc, dry matter, carbohydrates, ash and proteins. To achieve an improvement in $\mathrm{Ca} / \mathrm{P}$ ratio and amylopectin, Group 2 cultivars will be the most appropriated. However, Wouroutani and Labôkô cultivars of Group 1, Kpagninan and Deba of Group 2, and Portchahabim, Amoula, Kagourou, and Gominin of Group 3, can be considered as the best male parents and can be used to develop more efficient and nutritious cultivars.
The study of the proximate, sugars and mineral compositions of the 48 cultivars of Dioscorea rotundata yams used as parents in the breeding program in Benin showed significant $(\mathrm{P}<0.05)$ differences between cultivars. Cluster analysis groups into three main groups of nutritional interests. Result of mineral compositions revealed, mineral salt levels vary from one cultivar to another, with the exception of iron and iodine. The study also clarify the correlation between the parameters evaluated and this could represent a reliable database to orient future breeding programme for white yam (D. rotundata) improvement. In addition, almost all cultivars analyzed, contain high levels of carbohydrates with the exception of a few cultivars, such as Assinan. Out of all the cultivars evaluated, groups 1 and 3 cultivars are characterized with higher levels of sugars, lipids, proteins, carbohydrates, starch, amylopectin and dry matter with significant mineral contents, appear to be more promising for involvement in breeding programs.

\section{Acknowledgements}

This study was financially supported by AfricaYam project (BMGF). We express our sincere thanks to all the technicians who, directly or indirectly, contributed to this work.

\section{References}

Adejumo BA, Okundare RO, Afolayan OI, Balogun SA. 2013. Quality Attributes of Yam Flour (Elubo) as affected by blanching water temperature and soaking time. Intl. J. Engr. Sci. (IJES), 2(1): 216-221.

Adjatin A, Dansi A, Badoussi E, Dansi M, Azokpota P, Ahissou H, Akouegninou A, Akpagana K, Sanni A. 2013. Proximate, mineral and vitamin $\mathrm{C}$ composition of vegetable bolo [Crassocephalum rubens (Juss. ex 
Jacq.) S. Moore and C. crepidioides (Benth.) S. Moore] in Benin Int. J. Biol. Chem. Sci. 7(1): 319-331

Akinoso R, Olatoye K. 2013. Energy utilization and conservation in instant pounded yam flour production. International Food Research. 20(2): 575-579

Akissoe N, Hounhouigan DJ, Bricas N, Vernier P, Nago CM, Olorunda A. 2001. Physical, chemical and sensory evaluation of dried yam (Dioscorea rotundata) tubers, flour, and 'amala" a flour-derived product. Tropical Science, 41: $15-151$

Alinnor IJ, Akalezi CO. 2010. Proximate and mineral compositions of Dioscorea rotundata (white yam) and Colocasia esculenta (white cocoyam). Pakistan journal of nutrition, 9(10), 998-1001.

Alinnor IJ, Oze R. 2011. Chemical evaluation of the nutritive value of Pentaclethra macrophylla benth (African Oil Bean) Seeds. Pakistan Journal of Nutrition, 10(4): 355-359.

Andzouana M, Mombouli JB. 2012. Assessment of the Chemical and Phytochemical Constituents of the Leaves of a Wild VegetableOchthocharis dicellandroides (Gilg). Pakistan Journal of Nutrition, 11(1): 9499.

AOAC. 1990. Association of Official Analytical Chemists. Official methods of analysis chemists, 15thed (AOAC Arlington) Virginia, USA.

AOAC. 2000. Official methods of Analysis, Association of Official Analytical.

Atwater, W. O., \& Benedict, F. G. 1902. Experiments on the metabolism of matter and energy in the human body, 1898-1900. United States. Office of experiment stations. Bulletin, (109).

Baco MN, Tostain S, Mongbo RL, Biaou G, Lescure JP. 2007. Igname, plante alimentaire commerciale et culturelle au nord Bénin. Annales des sciences Agronomiques, 9(2) 49-67.

Badau, M. H., Abba, H. Z., Agbara, G. I., \& Yusuf, A. A. 2013. Proximate composition, mineral content and acceptability of granulated maize dumpling (Dambu Masara) with varying proportions of ingredients. Global advanced research journal of agricultural science, 2(1), 320-329.

Bahrani SA. 2013. Modification des propriétés physico-chimiques de l'amidon par procédés hygrothermiques : Contribution a l'étude des transferts couples chaleur-masse. Archives ouvertes HAL, 13-55.

Bertrand G, Thomas P. 1910. Guide pour les manipulations de chimie biologie. Paris Dunod et Pinat, p. 468.

Bourely, J. 1982. Observations on the determination of oil in cotton seed [methods]. Coton et Fibres Tropicales. ISSN : 0010-9711

Coulibaly A., Degbeu KC., Bekoin APM., Kouakoua E.Y., Pereko KKA., Dabonné S., Aman NG. 2019. Browning Prevention and Sensory Evaluation of Frozen Yam Slices (Dioscorea cayenensis-rotundata $\mathrm{Cv}$ Kponan) of Côte D'Ivoire. Asian Food Science Journal, 9(4): 1-10.

Degbeu KC., Adou M., Kouadio K.O. 2019. Influence of Technique Cultivation on Some Properties of Two Varieties of Yam (Dioscorea spp) Flour. Asian Journal of Advances in Agricultural Research, 10(4): 1-5.

Delali P, Emmanuel OA, Agnes KA. 2016. Rheological properties of Seven Different Yams (Dioscorea species) within the Yam Germplasm. International Journal of Innovation and Scientific Research: 445-452.

Egah J, and Baco MN. 2011. Dynamique de gestion de la biodiversité de l'igname face au développement du vivrier 
marchand au Nord-Bénin. Conference paper, 19-22 September 2011, University of York, 1-10.

Ehui FHC, Djedji A, Sako, Amani NG. 2009. Propriétés fonctionnelles des amidons de six variétés sélectionnées de manioc (Manihot esculenta Crantz): African journal, 84-85.

FAO. 2018. FAOSTAT Database. Food and Agriculture Organization, Roma, Italy.Avaible online at URL: www.fao.org

Gomez SM., Pokorny L., Kantar MB., Forest F., Leitch I.J., Gravendeel B., Wilkin P., Graham SW., Viruel J. 2019. A customized nuclear target enrichment approach for developing a phylogenomic baseline for Dioscorea yams (Dioscoreaceae). Applications in Plant Sciences, 7(6): e11254.

Graham-Acquaah, S., Ayernor, G. S., Bediako-Amoa, B., Saalia, F. K., Afoakwa, E. O. 2012. Spatial distribution of total phenolic content, enzymatic activities and browning in white yam (Dioscorea rotundata) tubers. Journal of Food Science and Technology, 51(10), 2833-2838. doi:10.1007/s13197-012-0760-6

Loko, Y. L., Dansi, A., Agre, A. P., Akpa, N., Dossou-Aminon, I., Assogba, P., \& Sanni, A. 2013. Perceptions paysannes et impacts des changements climatiques sur la production et la diversité variétale de l'igname dans la zone aride du nordouest du Bénin. International Journal of Biological and Chemical Sciences, 7(2), 672-695.

Medoua, G. N., Mbome, I. L., Agbor-Egbe, T., \& Mbofung, C. M. F. 2005. Physicochemical changes occurring during post-harvest hardening of trifoliate yam (Dioscorea dumetorum) tubers. Food chemistry, 90(4), 597-601.

Megh RB, Takanori K, Kawabata J. 2002. Nutritional evaluation of wild yam
(Dioscorea spp.) tubers of Nepal. Food chemistry; 060-8589.

Mestres C, Matencio F, Pons B, Yajid M, Fliedel G. 1996. Arapid method for the determination of amylose content by using Differential Scanning Calorimetry. Starch, 48(1), 2-6.

Minitab, L. L. C. 2017. Getting Started with Minitab 18. Minitab Inc., State College, $P A, U S A, 73$.

More S.J., Ravi V., Raju S. 2019. Tropical Tuber Crops. In: Tonetto de Freitas, S. (Ed.), Pareek, S. (Ed.). Postharvest Physiological Disorders in Fruits and Vegetables. Boca Raton: CRC Press, https://doi.org/10.1201/b22001.

Mulualem T, Mekbib F, Hussein S, Gebre E. 2018. Analysis of Biochemical Composition of Yams (Dioscorea spp.) Landraces from Southwest Ethiopia. Agrotechnology 7: 177 . doi: 10.4172/2168-9881.1000177.

Njintang YN, Mbofung CM, Balaam F, Kitissou P, Scher J. 2007. Effect of Taro (Colocasia esculenta) Flour Addition on The Functional and Alveographic Properties of Wheat Flour and Dough. Journal of the Science of Food and Agriculture 88(2), 273-279.

Nwankwo PO. 2019. Assessement of the phytonutrient content, Mineral and Proximate composition of selected yam Landraces (Dioscorea rotundata Poir). In Biochem Physiol, 4(3): 000157.

Padhan, B., Biswas, M., Panda, D. 2020. Nutritional, anti-nutritional and physico-functional properties of wild edible yam (Dioscorea spp.) tubers from Koraput, India. Food Bioscience, 100527. doi:10.1016/j.fbio.2020.100527

Polycarp, D., Afoakwa, E. O., Budu, A. S., Otoo, E. 2012. Characterization of chemical composition and antinutritional factors in seven species within the Ghanaian yam (Dioscorea) germplasm. International Food 
Research Journal 19 (3): 985-992.

R. 2013. A language and environment for statistical computing.

Rose-Monde M, Séverin KK, Eric Essoh A, Cathérine D, N'zué B, Sébastien NL .2009. Physico-chemical and biochemical characteristics of improved cassava varieties in Cote d'Ivoire.in Animal \& Plant Sciences (5) 507-514.

Sanoussi AF, Dansi A, Bokossa-yaou I, Dansi M, Egounlety M, Sanni LO, Sanni A. 2013. Formulation and biochemical characterization of sweet potato (Ipomoea batatas) based infant flours fortified with soybean and sorghum flours. Int.J.Curr.Microbiol.App.Sci (2013) 2(7): 22-34.

Sanoussi AF., Loko YL., Ahissou H., Soro S, Konan G, Elleingand E, N'guessan D, Koffi E. 2015. Formulation d'aliments infantiles à base de farines d'igname enrichie au soja. African journal of food agriculture, Nutrition and development; volume 13 (5): 1-27.

Soro, S., Konan, G., Elleingand, E., N'guessan, D., \& Koffi, E. 2013. Formulation d'aliments infantiles à base de farines d'igname enrichies au soja. African journal of food, agriculture, nutrition and development, 13(5), 83138339.

Tegegne B., Belay A., Gashaw T. 2020. Nutritional potential and mineral profiling of selected rice variety available in Ethiopia. Chemistry International 6(1): 21-29.

Udensi EA, Oselebe HO, Iweala OO. 2008. The investigation of chimical composition and functional proprieties of water yam (Dioscorea alata): Effec of varietal differences Pakistan journal of nutrition. 7 (2):342-344.

Umara I., Emenyonua VC. 2019. Assessing Impact of Gamma Irradiation on Proximate Composition of White Yam, Dioscorea Rotundata: Pepa Specie Farmed in Nasarawa State. Nigerian Journal of Environment and Health, 2:12-19.

Wada E., Feyissa T., Tesfaye K. 2019. Proximate, Mineral and Antinutrient Contents of Cocoyam (Xanthosoma sagittifolium (L.) Schott) from Ethiopia. International Journal of Food Science, Article ID 8965476, 7p.

Wolff, I. 1972. Microstrip bandpass filter using degenerate modes of a microstrip ring resonator. Electronics letters, 8(12), 302-303.

Yolou M, Zoundjihekpon J, Assaba EI, Anizehou I, Akoegninnou A. 2015. La floraison des ignames africaines cultivées ( $D$. cayenensis $-D$. rotundata et $D$. dumetorum) dans les champs des producteurs du Centre-Bénin. Journal of Applied Biosciences, 91(1), 8480-8492.

\section{How to cite this article:}

Fakorede Jeannette, Sanoussi Faouziath, Loko Yêyinou Laura Estelle, Dassou G. Anicet, Tchekessi Célestin, Ogundipe Oladeinde, Bokossa Yahou Innocent and Dansi A. Alexandre. 2020. Evaluation of Proximate, Sugars and Mineral Compositions of 48 Yam (Dioscorea rotundata) Cultivars used as Parents in a Breeding Program in Republic of Benin. Int.J.Curr.Microbiol.App.Sci. 9(03): 1663-1682. doi: https://doi.org/10.20546/ijcmas.2020.903.195 